\title{
Oxygen Plasma Treated-Electrospun Polyhydroxyalkanoate Scaffolds for Hydrophilicity Improvement and Cell Adhesion
}

\author{
Asiyah Esmail ${ }^{1,2,3}{ }^{\mathbb{D}}$, João R. Pereira ${ }^{1}$, Patrícia Zoio ${ }^{2,3}$, Sara Silvestre ${ }^{4} \mathbb{D}$, Ugur Deneb Menda ${ }^{4}$, Chantal Sevrin $^{5}$, \\ Christian Grandfils ${ }^{5}$, Elvira Fortunato ${ }^{4}$, Maria A. M. Reis ${ }^{1}$, Célia Henriques ${ }^{6}$, Abel Oliva ${ }^{2,3}$ (D) \\ and Filomena Freitas $1, *$ (D)
}

\section{check for} updates

Citation: Esmail, A.; Pereira, J.R.; Zoio, P.; Silvestre, S.; Menda, U.D.; Sevrin, C.; Grandfils, C.; Fortunato, E.; Reis, M.A.M.; Henriques, C.; et al. Oxygen Plasma Treated-Electrospun Polyhydroxyalkanoate Scaffolds for Hydrophilicity Improvement and Cell Adhesion. Polymers 2021, 13, 1056. https://doi.org/10.3390/ polym13071056

Academic Editor: Kalim Deshmukh

Received: 28 February 2021

Accepted: 24 March 2021

Published: 27 March 2021

Publisher's Note: MDPI stays neutral with regard to jurisdictional claims in published maps and institutional affiliations.

Copyright: (c) 2021 by the authors Licensee MDPI, Basel, Switzerland. This article is an open access article distributed under the terms and conditions of the Creative Commons Attribution (CC BY) license (https:// creativecommons.org/licenses/by/ $4.0 /)$.
1 UCIBIO-REQUIMTE, Chemistry Department, Nova School of Sciences and Technology, 2829-516 Caparica, Portugal; a.esmail@campus.fct.unl.pt (A.E.); jra.pereira@campus.fct.unl.pt (J.R.P.); amr@fct.unl.pt (M.A.M.R.)

2 ITQB NOVA-Instituto de Tecnologia Química e Biológica António Xavier, Nova University Lisbon, 2780-157 Oeiras, Portugal; patricia.zoio@itqb.unl.pt (P.Z.); oliva@itqb.unl.pt (A.O.)

3 iBET, Instituto de Biologia Experimental e Tecnológica, 2780-157 Oeiras, Portugal

4 CENIMAT/i3N, Materials Science Department, Nova School of Science and Technology, 2829-516 Caparica, Portugal; si.silvestre@campus.fct.unl.pt (S.S.); u.menda@fct.unl.pt (U.D.M.); emf@fct.unl.pt (E.F.)

5 CEIB-Interfaculty Research Centre of Biomaterials, University of Liège, B-4000 Liège, Belgium; csevrin@uliege.be (C.S.); c.grandfils@uliege.be (C.G.)

6 CENIMAT/i3N, Physics Department, Nova School of Sciences and Technology, 2829-516 Caparica, Portugal; crh@fct.unl.pt

* Correspondence: a4406@fct.unl.pt; Tel.: +35-12-1294-8300

Abstract: Poly(hydroxyalkanoates) (PHAs) with differing material properties, namely, the homopolymer poly(3-hydroxybutyrate), $\mathrm{P}(3 \mathrm{HB})$, the copolymer poly(3-hydroxybutyrate-co-3-hydroxyvalerate), $\mathrm{P}(3 \mathrm{HB}-\mathrm{co}-3 \mathrm{HV})$, with a $3 \mathrm{HV}$ content of $25 \mathrm{wt} . \%$ and a medium chain length PHA, and mcl-PHA, mainly composed of 3-hydroxydecanoate, were studied as scaffolding material for cell culture. $\mathrm{P}(3 \mathrm{HB})$ and $\mathrm{P}(3 \mathrm{HB}-\mathrm{co}-3 \mathrm{HV})$ were individually spun into fibers, as well as blends of the mcl-PHA with each of the scl-PHAs. An overall biopolymer concentration of $4 \mathrm{wt}$. $\%$ was used to prepare the electrospinning solutions, using chloroform as the solvent. A stable electrospinning process and good quality fibers were obtained for a solution flow rate of $0.5 \mathrm{~mL} \mathrm{~h}^{-1}$, a needle tip collector distance of $20 \mathrm{~cm}$ and a voltage of $12 \mathrm{kV}$ for $\mathrm{P}(3 \mathrm{HB})$ and $\mathrm{P}(3 \mathrm{HB}-\mathrm{co}-3 \mathrm{HV})$ solutions, while for the mcl-PHA the distance was increased to $25 \mathrm{~cm}$ and the voltage to $15 \mathrm{kV}$. The scaffolds' hydrophilicity was significantly increased under exposure to oxygen plasma as a surface treatment. Complete wetting was obtained for the oxygen plasma treated scaffolds and the water uptake degree increased in all treated scaffolds. The biopolymers crystallinity was not affected by the electrospinning process, while their treatment with oxygen plasma decreased their crystalline fraction. Human dermal fibroblasts were able to adhere and proliferate within the electrospun PHA-based scaffolds. The $\mathrm{P}(3 \mathrm{HB}-\mathrm{co}-3 \mathrm{HV})$ : mcl-PHA oxygen plasma treated scaffold highlighted the most promising results with a cell adhesion rate of $40 \pm 8 \%$, compared to $14 \pm 4 \%$ for the commercial oxygen plasma treated polystyrene scaffold Alvetex $^{\mathrm{TM}}$. Scaffolds based on $\mathrm{P}(3 \mathrm{HB}-\mathrm{co}-3 \mathrm{HV})$ : mcl-PHA blends produced by electrospinning and submitted to oxygen plasma exposure are therefore promising biomaterials for the development of scaffolds for tissue engineering.

Keywords: poly(hydroxyalkanoates); electrospinning; oxygen plasma; biocompatibility

\section{Introduction}

A scaffold is a 3D structure made of synthetic, natural or mixed components that serves as support for cellular proliferation and differentiation, in view to mimic the microstructure, mechanical properties and biochemical functionality of living tissues [1-3]. This material should fulfil to several specifications before considering its medical application. Amongst 
other, it should be a biocompatible and non-immunogenic and should present an interconnected open-pore geometry with pore size allowing cell colonization, adhesion, growth and reorganization [1,4]. Moreover, mechanical properties should sustain the structure required for cell ingrowth and matrix formation [1,5]. Scaffolds made of a wide variety of materials, including natural and synthetic polymers, recombinant proteins, ceramics and metal composites. Some of them have been able to generate in vitro different biological tissue-like structures (blood vessels [6], skin [7], bone [8] and gut [9]) with potential applications in translational research, drug discovery and clinical transplantation or $[3,10]$.

The selection of a scaffold architecture and material depends on the specific tissue engineering application [11]. Although synthetic materials, like synthetic polymers and bioactive glasses, are advantageous for their defined composition, the possibility they offer to tailor the scaffold mechanical properties and degradability, they may lack sites for cellular adhesion [12,13]. Natural materials, such as poly(hydroxyalkanoates) (PHAs), gelatin and chitosan, offer biocompatibility and cellular interaction, besides being biodegradable into non-toxic by-products [14-17]. However, being from natural origin, variability from batch to batch has been reported $[3,11,18]$. Fibrous scaffolds have attracted considerable attention because their fibers form a network that mimics the extracellular matrix (ECM) which is structurally convenient to promote cell adhesion, proliferation, differentiation and matrix deposition. Despite the large volume scaffolds being difficult to make, which limits this technique scale-up, electrospinning is a versatile technology giving rise to sub-micrometric and randomly oriented fiber networks with high porosity and interconnected pores, i.e., similar to the extracellular matrix (ECM) $[19,20]$.

PHAs are biopolyesters synthesized as intracellular carbon and energy reserves by many bacteria and Archeae [21]. Mechanical properties of PHAs can range from stiff and brittle polymers, such as poly(3-hydroxybutyrate) $\mathrm{P}(3 \mathrm{HB})$, to elastomers such as the medium-chain length PHAs (mcl-PHAs) $[13,21,22] . \mathrm{P}(3 \mathrm{HB})$ is a highly crystalline $( \pm 70 \%)$ homopolymer with a melting temperature of $173-180{ }^{\circ} \mathrm{C}$ [23]. Poly(3-hydroxybutyrateco-3-hydroxyvalerate), $\mathrm{P}(3 \mathrm{HB}-\mathrm{co}-3 \mathrm{HV})$, a copolymer of $3 \mathrm{HB}$ and $3 \mathrm{HV}$ monomers, has lower crystallinity $(52-73 \%)$ and melting point $\left(137-170{ }^{\circ} \mathrm{C}\right)$, conferred by the presence of 3HV monomers [23-25]. Mcl-PHAs are composed of 6-14 carbon atoms monomers (e.g., 3-hydroxyhexanoate (3HHx), 3-hydroxyoctanoate (3HO), 3-hydroxydecanoate (3HD)) and are mostly amorphous, with crystallinity degrees below $40 \%$ and have low melting temperatures $\left(40-60{ }^{\circ} \mathrm{C}\right)[21,22]$.

PHAs characteristics, such as biocompatibility, biodegradability and customizability, make them suitable candidates for the fabrication of scaffolds intended for cell culture [22-26]. The fabrication of biocompatible PHA-based electrospun scaffolds has been reported for several PHAs, namely, P(3HB) [27,28], P(3HB-co-3HHx) [28], P(3HB-4HB-3HV) [29] and $\mathrm{P}(3 \mathrm{HB}-\mathrm{co}-3 \mathrm{HV})[30,31]$. However, electrospun fibers of mcl-PHAs are tacky and sticky at room temperature, which leads to loss of shape on collection and makes the production of fibrous scaffolds unfeasible. Blending a mcl-PHA with a scl-PHA allowed to overcome this difficulty, resulting in electrospun fibers with improved mechanical properties and degradation rate when compared to those made of the scl-PHA alone [32]. A melt processing technique was employed for the preparation of a bionanocomposite of a scl-PHA with bacterial cellulose nanofibers, resulting in scaffolds with suitable physical and biological properties [33]. PHA-based scaffolds still suffer from a few limitations, including their intrinsic hydrophobicity that hinders their use for animal cell culture. Surface treatments (e.g., oxygen or $\mathrm{CO}_{2}$ plasma) are typically adopted to modify the surface properties of PHA-based materials [34-39], such as roughness, wettability and biocompatibility. These surface treatments are indeed introducing functional groups with oxygen atoms (e.g., grafted ester, carboxyl or carbonyl groups) [38], with significant improvement in terms of bioactivity [40].

In this work, PHA-based fibrous scaffolds were developed via electrospinning and tested as a platform for in vitro cell-culture. Different types of PHAs were tested, including $\mathrm{P}(3 \mathrm{HB}), \mathrm{P}(3 \mathrm{HB}-\mathrm{co}-3 \mathrm{HV})$ and mcl-PHA and their corresponding blends. Furthermore, the 
electrospun scaffolds were exposed to oxygen plasma to render them higher hydrophilic character. The novel structures where then characterized for their physical, chemical and biological properties.

\section{Materials and Methods}

\subsection{Biopolymers}

The homopolymer $\mathrm{P}(3 \mathrm{HB})$ and the copolymer $\mathrm{P}(3 \mathrm{HB}-\mathrm{co}-3 \mathrm{HV})$, with a $3 \mathrm{HV}$ content of 25 wt.\%, were obtained by cultivation of Cupriavidus necator DSM 428 (purchased from DSMZ, the German Collection of Microorganisms and Cell Cultures, Braunschweig, Germany) with used cooking oil as carbon source, as described by Cruz et al. [41]. For the production of the copolymer, levulinic acid was used as co-substrate in a fed-batch mode, as described by Wang et al. [42]. An mcl-PHA composed of $64 \mathrm{wt} . \% 3 \mathrm{HD}, 16 \mathrm{wt} \%$ 3HO, $12 \mathrm{wt} . \% 3 \mathrm{HDd}$ and $7 \mathrm{wt} . \%$ 3HTd was obtained by cultivation of Pseudomonas chlororaphis DSM 19603 (purchased from DSMZ, Braunschweig, Germany), using glycerol as carbon source, as described by Meneses et al. [43]. The biopolymers were extracted from the lyophilized biomass by using a Soxhlet extraction with chloroform (Sigma-Aldrich, $\geq 99.8 \%$, Darmstadt, Germany) and purified by precipitation in ice-cold ethanol (Carlo Erba Reagents, Cornaredo, Italy), as described by Pereira et al. [44].

\subsection{Preparation of PHA-Based Scaffolds \\ 2.2.1. Electrospinning}

The biopolymers were dissolved in chloroform (Sigma-Aldrich, $\geq 99.8 \%$, Darmstadt, Germany) at concentrations of $4 \mathrm{wt} . \%$, for $\mathrm{P}(3 \mathrm{HB})$ and $\mathrm{P}(3 \mathrm{HB}-\mathrm{co}-3 \mathrm{HV})$, or 12 and $25 \mathrm{wt} . \%$, for the mcl-PHA. Blends of mcl-PHA with either $\mathrm{P}(3 \mathrm{HB})$ or $\mathrm{P}(3 \mathrm{HB}-\mathrm{co}-3 \mathrm{HV})$ were prepared at an overall biopolymer concentration of $4 \mathrm{wt} . \%$, with scl-/mcl-PHA adopting weight compositional ratios of 50:50, 60:40 and 70:30. The electrospinning apparatus consisted of a syringe pump (NE-1000 Programmable Single Syringe Pump, New Era PumpSystemsInc, Farmingdale, NY, USA), a high-voltage power supply (T1CP300304p, ISEG, Radeberg, Germany) and a homemade grounded slowly rotating collector. A $5 \mathrm{~mL}$ syringe containing the polymer solution was loaded into the syringe pump and a metallic blunt tip needle with an inner diameter of $0.508 \mathrm{~mm}$ was attached to the syringe. A voltage was applied to the needle by means of the high-voltage supply. The electrospun mats were collected on a grounded planar plate covered by an aluminum foil. Different electrospinning parameters were studied, namely, polymer concentration, voltage $(8,10,12$ and $15 \mathrm{kV})$, solution feeding rate $\left(0.5\right.$ and $\left.1.0 \mathrm{~mL} \mathrm{~h}^{-1}\right)$ and needle-collector distance $(20$ and $25 \mathrm{~cm})$. To monitor the result of the process according to the studied parameters, the fibers were collected for a few seconds onto a glass slide in contact with the aluminum foil. The glass slide was then observed under an optical microscope (Visiscope TL524PI, VWR, Alfragide, Portugal) equipped with a camera (Visicam3.0, VWR, Alfragide, Portugal). The experiments were performed at room temperature.

\subsubsection{Oxygen Plasma Treatment}

The electrospun scaffolds were mounted on a silicon wafer with the aid of carbon tape. Samples were placed on a reactive ion etching (RIE) system (Trion Minilock Phantom III, Clearwater, FL, USA) and treated with oxygen plasma (Figure 1a). A plasma treatment of $12 \mathrm{~min}$, at a pressure of $100 \mathrm{mTorr}$ and $\mathrm{O}_{2}$ flow rate of $10 \mathrm{sccm}$ was performed. A hydrophilic surface was obtained, as schematically shown in Figure 1b). 


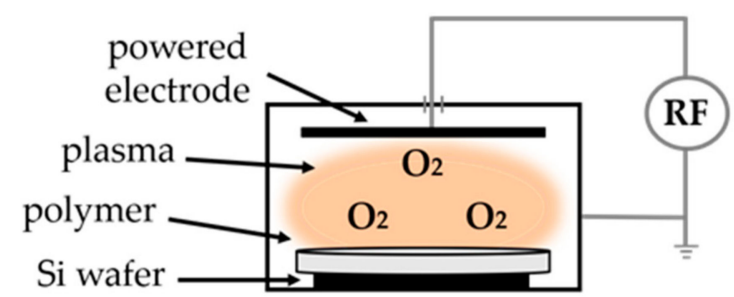

(a)

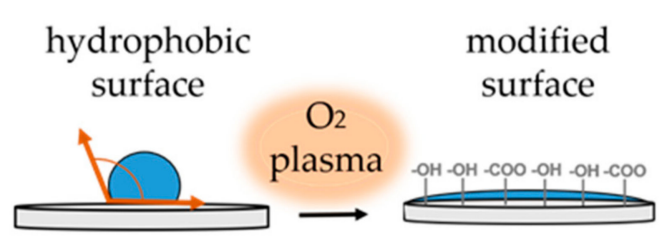

(b)

Figure 1. Schematic drawing of the oxygen plasma treatment (a) and the resulting modified surface (b).

\subsection{Characterization}

2.3.1. Molecular Mass Distribution of the Biopolymers

Number and weight average molecular weights, $M_{n}$ and $M_{w}$, respectively and the polydispersity index ( $P D I=M_{n} / M_{w}$ ) of the samples were determined by a size exclusion chromatography (SEC) System (Waters Millenium, Milford, MA, USA), using monodisperse polystyrene standards (800-504,000 Da), as described by Pereira et al. [44].

\subsubsection{Thermal Analysis}

Differential scanning calorimetry (DSC) analysis was carried out in a DSC25 Discovery Series (TA Instruments, New Castle, DE, USA) equipped with a cooling system, System 90 (TA Instruments, New Castle, DE, USA). The samples were placed in aluminum crucibles and analyzed in the temperature range between $-90^{\circ} \mathrm{C}$ and $200{ }^{\circ} \mathrm{C}$, at heating and cooling rates of $10{ }^{\circ} \mathrm{C} \mathrm{min}^{-1}$ under $\mathrm{N}_{2}$ atmosphere. Three thermal cycles were performed. The melting temperature $\left(T_{m},{ }^{\circ} \mathrm{C}\right)$ was determined at the minimum of the endothermic peak. The crystallinity $\left(X_{c}, \%\right)$ of the samples was estimated as the ratio between melting enthalpy $\left(\Delta H_{m}, \mathrm{~J} \mathrm{~g}^{-1}\right)$ of its melting peak and the melting enthalpy of a $100 \%$ crystalline $\mathrm{P}(3 \mathrm{HB})$, earlier reported by Morais et al. [45] and equal to $146 \mathrm{~J} \mathrm{~g}^{-1}$. Thermogravimetric Analysis (TGA) was performed with a Labsys EVO (Setaram Instrumentation, France). Samples were placed in aluminium crucibles and analyzed in the temperature range between 25 and $500{ }^{\circ} \mathrm{C}$, at $10{ }^{\circ} \mathrm{C} \mathrm{min}^{-1}$.

\subsubsection{Scanning Electron Microscopy (SEM)}

Samples of the electrospun scaffolds were mounted for SEM observation using double sided carbon tape and aluminum stubs and sputter coated with gold-palladium $(60 \% / 40 \%)$ alloy (Q150T ES, Quorum, Lewes, UK). The analysis was performed using a bench top scanning electron microscope (TM3030 Plus, Hitachi, Tokyo, Japan) using an acceleration voltage of $15 \mathrm{kV}$. The obtained SEM images were processed by ImageJ.

\subsubsection{Water Contact Angle and Water Uptake Degree}

The water contact angle of the scaffolds was determined by the sessile drop method, as described by Rebocho et al. [46], using a CAM 200 goniometer (KSV Instruments Ltd., Espoo, Finland). For determination of the water uptake degree, scaffolds samples with a size of $1.0 \times 1.0 \mathrm{~cm}^{2}$ were cut and weighted and their thickness was measured with a micrometer (Elcometer, Manchester, England). The samples were immersed in deionized water $(15 \mathrm{~mL})$, in closed vials that were kept at $30^{\circ} \mathrm{C}$, during $24 \mathrm{~h}$. The water uptake degree of each sample was calculated with the following Equation:

$$
\text { Water uptake degree }(\%)=\frac{X 2-X 1}{X 1} \times 100
$$

where $X 1$ is the initial mass of the dry sample and $X 2$ its final mass after swelling. The samples thickness after immersion was also measured. 


\subsection{Biological Assays}

\subsubsection{Cell Culture}

Primary human dermal fibroblasts from neonatal foreskin (HDFn) (CellnTec, Bern, Switzerland) were maintained in Fibroblast Growth medium (FGM) composed of Iscove's Modified Dulbecco's Medium (IMDM) with Glutamax ${ }^{\mathrm{TM}}$ (Thermo Fisher Scientific, Waltham, MA, USA) supplemented with 10\% Fetal Bovine Serum (FBS, Thermo Fisher Scientific, Waltham, MA, USA) and 0.1\% Penicillin-Streptomycin (Penstrep, Thermo Fisher Scientific, Waltham, MA, USA). HDFns were incubated at $37^{\circ} \mathrm{C}, 5 \% \mathrm{CO}_{2} / 95 \%$ humidified air in a cell culture incubator and subcultured at confluency of $90 \%$, following supplier's instructions. HDFns between passages 4 and 7 were used for all experiments for reproducibility purposes.

\subsubsection{Cell Seeding}

The scaffolds were cut into circles of $1.5 \mathrm{~cm}$ in diameter to fit the wells of 24-well plates and sterilized under a 22-Watt UV lamp. Three biological replicates and three technical replicates for each biological replicate were performed. The assays were performed in triplicate. Inert polystyrene scaffolds (Alvetex ${ }^{\mathrm{TM}}$, Reprocell Europe, Glasgow, UK) were pre-treated with $70 \%$ ethanol followed by two washes with PBS. HDFns $\left(2 \times 10^{4}\right.$ cells $)$ were seeded onto each scaffold and on empty wells (control) and maintained in FGM for $48 \mathrm{~h}$ at $37^{\circ} \mathrm{C}$ in a $5 \% \mathrm{CO}_{2} / 95 \%$ humidified incubator.

\subsubsection{Cell Viability (MTT Assay)}

Cell viability was assayed using an MTT (thiazolyl blue tetrazolium bromide, SigmaAldrich) solution (5 $\mathrm{mg} \mathrm{mL}^{-1}$ in PBS). The MTT solution $(40 \mu \mathrm{L})$ was added to seeded scaffolds and the plates were incubated at $37^{\circ} \mathrm{C}$, for $4 \mathrm{~h}$. After incubation, the MTT solution was removed and $200 \mu \mathrm{L}$ of the extraction solution (89\% isopropanol, $10 \%$ Triton-X, $1 \%$ $\mathrm{HCl} 0.37 \%)$ was added to the wells. The plates were agitated in an orbital shaker for $10 \mathrm{~min}(150 \mathrm{rpm})$ and incubated with the extraction solution for $2 \mathrm{~h}$, at room temperature in the absence of light, to allow dissolution of formazan crystals. The content of each well was homogenized and $200 \mu \mathrm{m}$ were transferred to a 96-well plate. The absorbance was measured at $570 \mathrm{~nm}$. Triplicates of each type of scaffold were used in every assay. MTT assays were performed three times, in the same conditions, for statistical relevance. The results were submitted to statistical analysis with ordinary one-way ANOVA (GraphPad Prism 8.2.0, San Diego, CA, USA).

\subsubsection{Cell Morphology}

To assess cell morphology, the cells were fixed with $2.5 \%$ glutaraldehyde (Carl Roth) for one hour, at room temperature. The scaffolds were subsequently washed with PBS $(1 \times)$ and distilled water $(2 \times)$, for $2 \mathrm{~min}$ and dehydrated with a graded ethanol in deionized water series $(25 \%, 50 \%, 75 \%, 95 \%$ and $100 \%)$. Each exchange took $5 \mathrm{~min}$, except the final one that was repeated twice, with a duration of $10 \mathrm{~min}$. After drying in a fume hood, the scaffolds were stored in a desiccator until observation by SEM as described above.

\section{Results and Discussion}

\subsection{Biopolymers Characterization}

The homopolymer $\mathrm{P}(3 \mathrm{HB})$ and the copolymer $\mathrm{P}(3 \mathrm{HB}-\mathrm{co}-3 \mathrm{HV})$ had similar $\mathrm{M}_{\mathrm{w}}$ values $\left(5.2 \times 10^{5}\right.$ and $5.6 \times 10^{5} \mathrm{Da}$, respectively) (Table 1$)$. $\mathrm{P}(3 \mathrm{HB})$ had a polydispersity index (PDI) of 1.80, which is only slightly higher than that of $\mathrm{P}(3 \mathrm{HB}-\mathrm{co}-3 \mathrm{HV})(1.60) . \mathrm{P}(3 \mathrm{HB})$ had a melting temperature $\left(T_{m}\right)$ of $173.5^{\circ} \mathrm{C}$ (Figure 2a) and its thermal degradation $\left(T_{\text {deg }}\right)$ occurs at $293{ }^{\circ} \mathrm{C}$ (Table 1$)$. The copolymer's $T_{m}$ and $T_{\text {deg }}$ values were similar (171 and $292{ }^{\circ} \mathrm{C}$, respectively) to those found for the homopolymer. $\mathrm{P}(3 \mathrm{HB})$ melting enthalpy and crystallinity (76.6 $\mathrm{J} \mathrm{g}^{-1}$ and $52.4 \%$, respectively) were lower than those of $\mathrm{P}(3 \mathrm{HB}-\mathrm{co}-3 \mathrm{HV})$ ( $34.5 \mathrm{~J} \mathrm{~g}^{-1}$ and $23.6 \%$, respectively), which could be assigned to its $3 \mathrm{HV}$ content (25 wt. $\%$ ). 
Table 1. Molecular mass distribution and thermal properties of the biopolymers $\mathrm{P}(3 \mathrm{HB}), \mathrm{P}(3 \mathrm{HB}-\mathrm{co}-$ $3 \mathrm{HV}$ ) and the mcl-PHA, as well as those of the scaffolds obtained by electrospinning and after oxygen plasma treatment $\left(\mathrm{M}_{\mathrm{W}}\right.$, molecular weight; $\mathrm{PDI}$, polydispersity index; $T_{m}$, melting temperature; $T_{\text {deg }}$, degradation temperature; $X_{c}$, crystallinity fraction; $\Delta H_{m}$, melting enthalpy).

\begin{tabular}{|c|c|c|c|c|c|c|}
\hline Processing/Material & $\mathrm{M}_{\mathrm{w}}(\mathrm{Da})$ & PDI & $T_{m}\left({ }^{\circ} \mathrm{C}\right)$ & $T_{d e g}\left({ }^{\circ} \mathrm{C}\right)$ & $\Delta H_{m}\left(\mathrm{~J} \mathrm{~g}^{-1}\right)$ & $X_{c}(\%)$ \\
\hline \multicolumn{7}{|c|}{ None } \\
\hline $\mathrm{P}(3 \mathrm{HB})$ & $5.20 \times 10^{5}$ & 1.80 & 176 & 293 & 76.5 & 52.4 \\
\hline $\mathrm{P}(3 \mathrm{HB}-\mathrm{co}-3 \mathrm{HV})$ & $5.60 \times 10^{5}$ & 1.60 & 171 & 292 & 34.5 & 23.6 \\
\hline mcl-PHA & $0.69 \times 10^{5}$ & 1.50 & 48 & 292 & 8.2 & 5.6 \\
\hline \multicolumn{7}{|c|}{ Electrospinning } \\
\hline $\mathrm{P}(3 \mathrm{HB})$ scaffold & $4.20 \times 10^{5}$ & 1.63 & 173 & 289 & 77.5 & 53.1 \\
\hline $\mathrm{P}(3 \mathrm{HB}-\mathrm{co}-3 \mathrm{HV})$ scaffold & $4.10 \times 10^{5}$ & 1.68 & 167 & 288 & 36.1 & 24.7 \\
\hline $\begin{array}{c}\text { P(3HB-co-3HV): } \\
\text { mcl-PHA blend scaffold }\end{array}$ & $3.50 \times 10^{5}$ & 2.79 & $168 / 46$ & 290 & 30.5 & 20.9 \\
\hline \multicolumn{7}{|c|}{ Electrospinning $+\mathrm{O}_{2}$ Plasma Treatment } \\
\hline $\mathrm{P}(3 \mathrm{HB})$ scaffold & $3.50 \times 10^{5}$ & 1.90 & 171 & 291 & 56.6 & 38.8 \\
\hline $\mathrm{P}(3 \mathrm{HB}-\mathrm{co}-3 \mathrm{HV})$ scaffold & $3.50 \times 10^{5}$ & 2.00 & 168 & 293 & 26.3 & 18.0 \\
\hline $\begin{array}{c}\text { P(3HB-co-3HV): } \\
\text { mcl-PHA blend scaffold }\end{array}$ & $3.50 \times 10^{5}$ & 2.90 & $168 / 46$ & 293 & 14.9 & 10.2 \\
\hline
\end{tabular}
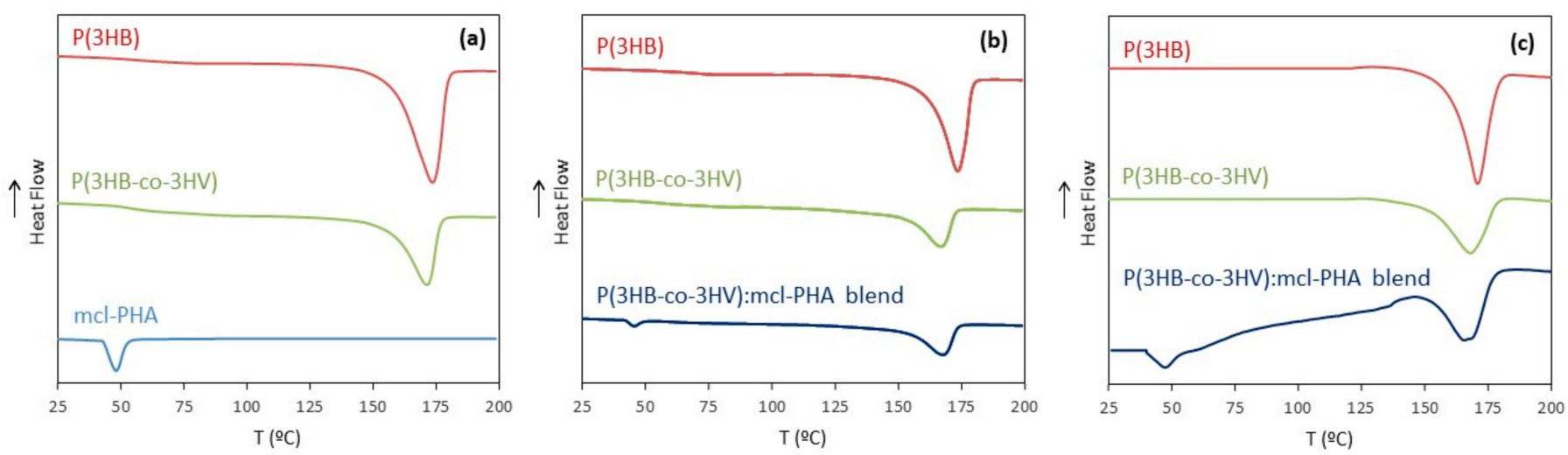

Figure 2. Differential scanning calorimetry (DSC) thermograms for (a) the untreated biopolymers, (b) the electrospun scaffolds and (c) the oxygen plasma treated electrospun scaffolds (red: $\mathrm{P}(3 \mathrm{HB})$, green: $\mathrm{P}(3 \mathrm{HB}-\mathrm{co}-3 \mathrm{HV})$, light blue: mcl-PHA in (a), dark blue: $\mathrm{P}(3 \mathrm{HB}-\mathrm{co}-3 \mathrm{HV})$ : mcl-PHA blend in $(\mathbf{b}, \mathbf{c}))$.

The mcl-PHA, which was mainly composed of 3HD (64 wt\%), with lower contents of $3 \mathrm{HO}(16 \mathrm{wt} . \%), 3 \mathrm{HDd}(12 \mathrm{wt} . \%)$ and $3 \mathrm{HTd}(7 \mathrm{wt} . \%)$, had a lower $\mathrm{M}_{\mathrm{w}}\left(0.69 \times 10^{5} \mathrm{Da}\right)$ and lower PDI (1.50) than the scl-PHAs (Table 1). When compared to the scl-PHAs values (Table 1), the mcl-PHA's Tm was considerably lower $\left(48^{\circ} \mathrm{C}\right)$, while the $T_{\text {deg }}$ was identical $\left(292{ }^{\circ} \mathrm{C}\right)$. The biopolymer was also less crystalline than the scl-PHAs, with a melting enthalpy of $8.2 \mathrm{~J} \mathrm{~g}^{-1}$ and a crystallinity degree of $5.6 \%$, all features readily explained by the presence of monomers with a high number of carbon atoms [47].

\subsection{Scaffolds Preparation}

3.2.1. Electrospun Scaffolds Based on $\mathrm{P}(3 \mathrm{HB}), \mathrm{P}(3 \mathrm{HB}-\mathrm{co}-3 \mathrm{HV})$ and mcl-PHA

Each biopolymer was dissolved in chloroform, which is one of the best solvents for PHAs [48]. Moreover, chloroform's volatility allows for the complete solvent evaporation during the flight of the polymeric jet towards the collector, preventing the collection of a network of ribbon-shaped and fused fibers $[49,50]$. In order to successfully electrospin a solution, viscosity should be adequate: High enough to prevent the jet breaking or the formation beaded fibers but not too high to allow jet stretching. For a given solvent- 
polymer system, solution viscosity increases with both the polymer molecular mass and concentration and so adequate polymer concentrations may be not within a narrow range of values. Chloroform has been used in several studies to prepare PHAs solutions for electrospinning, with concentrations around 2-17 wt.\%, for scl-PHAs [26,27,29,32] and $2-50 \mathrm{wt} . \%$ for mcl-PHAs [27,28,32]. In this study, a polymer concentration of $4 \mathrm{wt} . \%$ was used for the scl-PHAs, while for the mcl-PHA, higher concentrations (12 and $25 \mathrm{wt} . \%$ ) were tested.

For preparation of the scaffolds, electrospinning process parameters were tested, namely, the needle tip collector distance, $d$, the solution flow rate, $\phi$ and the voltage applied to the needle, $V$, aiming at defining a set of parameters leading to regular shaped fibres [51]. For both $\mathrm{P}(3 \mathrm{HB})$ and $\mathrm{P}(3 \mathrm{HB}-\mathrm{co}-3 \mathrm{HV})$ solutions, the distance was fixed at $20 \mathrm{~cm}$ and flow rates of 0.5 and $1.0 \mathrm{~mL} \mathrm{~h}^{-1}$ were tested for a voltage of $10 \mathrm{kV}$. For $d=20 \mathrm{~cm}$ and $\phi=0.5 \mathrm{~mL} \mathrm{~h}^{-1}$, voltages were varied between 8 and $15 \mathrm{kV}$. At $8 \mathrm{kV}$, some bead formation was observed for $\mathrm{P}(3 \mathrm{HB})$, which could be related to insufficient electric repulsion inside the polymeric jet able to stretch it, counteracting the force due to surface tension. On the other hand, for $\mathrm{P}(3 \mathrm{HB}-\mathrm{co}-3 \mathrm{HV})$, although smoother fibers were obtained, some blockage of the metallic tip occurred due to an unbalance between the solution feed rate and of the ability of the electric field to move the charged solution away from the tip of the needle (extracting rate). The accumulation of solution at the needle tip hinders the uninterrupted fiber formation. As the voltage was increased to 10,12 and $15 \mathrm{kV}$, smoother fibers were obtained for both polymer solutions. However, the deposition of the fibers onto the collector was more stable at $12 \mathrm{kV}$. Increasing the flow rate to $1.0 \mathrm{~mL} \mathrm{~h}^{-1}$, for a voltage of $10 \mathrm{kV}$, resulted in unstable electrospinning process, indicating that the feeding rate was higher than the electric field extraction rate. The parameters that lead to a stable process and good quality fibers were selected to electrospin both solutions (Table 2).

Table 2. Parameters selected to electrospin the biopolymers' solutions.

\begin{tabular}{cccc}
\hline Solution & $\boldsymbol{d}(\mathbf{c m})$ & $\boldsymbol{\phi}\left(\mathbf{m L ~ h} \mathbf{h}^{-\mathbf{1}}\right)$ & $\boldsymbol{V} \mathbf{( \mathbf { k V } )}$ \\
\hline $\mathrm{P}(3 \mathrm{HB})$ & 20 & 0.5 & 12 \\
$\mathrm{P}(3 \mathrm{HB}-c 0-3 \mathrm{HV})$ & 20 & 0.5 & 12 \\
$\mathrm{P}(3 \mathrm{HB}-c 0-3 \mathrm{HV})$ : mcl-PHA blend & 25 & 0.5 & 15 \\
\hline
\end{tabular}

Contrary to $\mathrm{P}(3 \mathrm{HB})$ and $\mathrm{P}(3 \mathrm{HB}-\mathrm{co}-3 \mathrm{HV})$, no fibers were obtained from the mcl-PHA solution, which could be related to the lower viscosity of the solutions. However, even at concentrations of 12 and $25 \mathrm{wt} . \%$ it was not possible to obtain fibers and only dots of polymer could be observed at the collector. This difficulty in obtaining electrospun mcl-PHA fibers has been reported by Li et al. [32] that suggested it was due to the lower molecular weight of mcl-PHA, as well as to the branching of the polymer, which can hinder chain entanglement. Blending mcl-PHA with other biocompatible polymers or scl-PHAs is the most common strategy to obtain fibers that incorporate mcl-PHA, while enabling fiber formation $[27,28,32,52]$.

\subsubsection{Electrospun Scaffolds Based on scl-/mcl-PHA Blends}

$\mathrm{P}(3 \mathrm{HB})$ : mcl-PHA and $\mathrm{P}(3 \mathrm{HB}-\mathrm{co}-3 \mathrm{HV})$ : mcl-PHA solutions in chloroform at different weight blend ratios (50:50, 60:40 and 70:30), with an overall polymer concentration of $4 \mathrm{wt} . \%$, were tested to produce fibers by electrospinning. Processing parameters were fixed at the following values: $d=25 \mathrm{~cm}, V=15 \mathrm{kV}$ and $\phi=0.5 \mathrm{~mL} \mathrm{~h}^{-1}$.

For P(3HB): mcl-PHA blend ratios of 50:50 and 60:40, beaded-fibers were obtained (Figure $3 a, c)$. This may be due to a relatively high surface tension and low viscosity of the spinning solutions. As the blend ratio increased to 70:30, fibers became much smoother (Figure 3e). Comparable results were obtained by Azari et al. [51], for blends of $\mathrm{P}(3 \mathrm{HB})$ and a palm oil-based mcl-PHA, dissolved in a mixture of chloroform and dimethylformamide (DMF). However, bead-less fibers where only produced with a $\mathrm{P}(3 \mathrm{HB})$ : mcl-PHA ratio of 80:20, a lower mcl-PHA incorporation when compared to that in our study. 


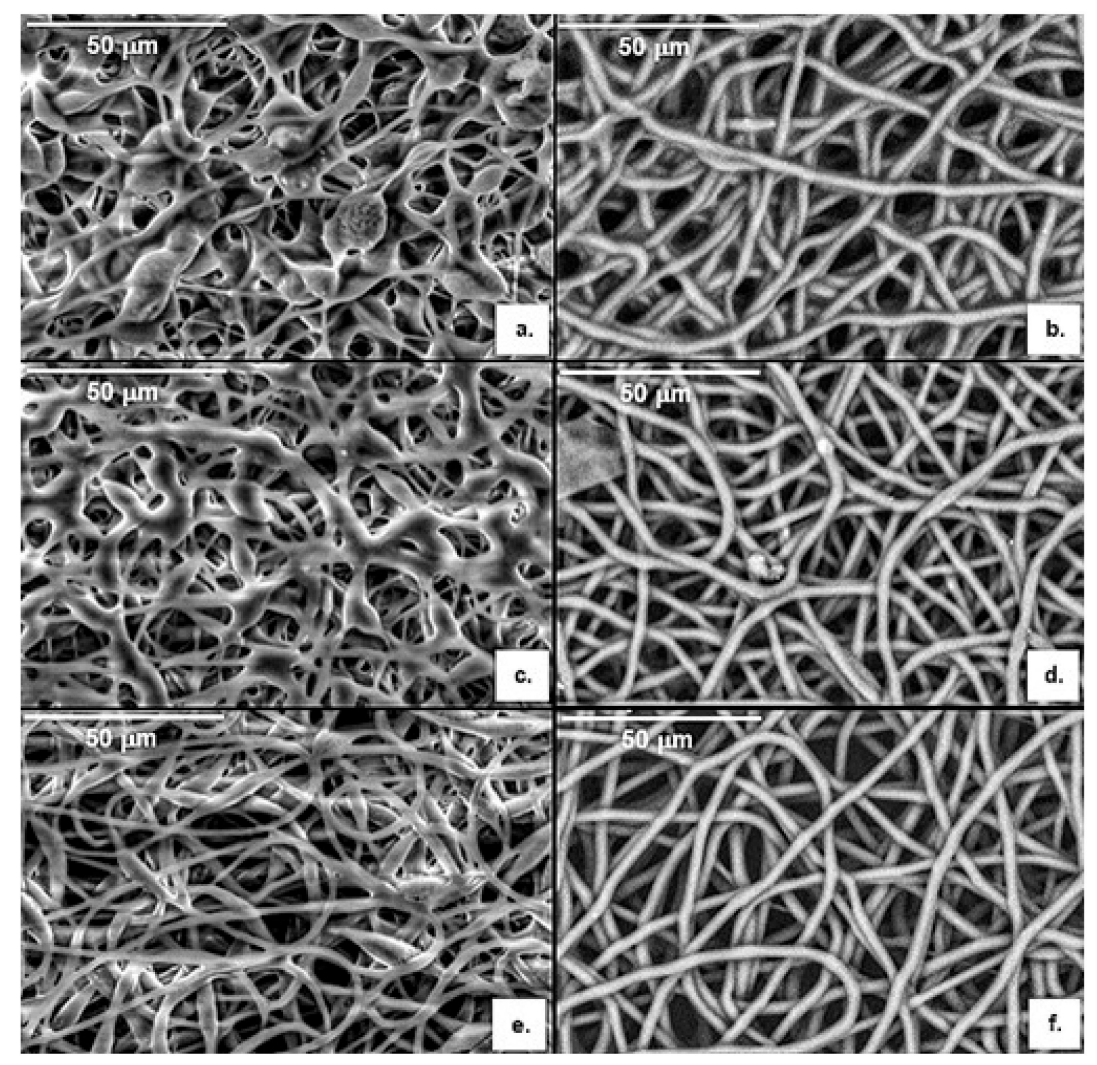

Figure 3. Images obtained by Scanning Electron Microscopy (SEM) analysis of the electrospun $\mathrm{P}(3 \mathrm{HB})$ : mcl-PHA fibers at blend ratios of 50:50 (a), 60:40 (c) and 70:30 (e) and the electrospun $\mathrm{P}(3 \mathrm{HB}-\mathrm{co}-3 \mathrm{HV})$ : mcl-PHA fibers at blend ratios of 50:50 (b), 60:40 (d) and 70:30 (f).

For the copolymer blends with the mcl-PHA, smooth bead-free microfibres were obtained for all tested ratios (Figure $3 b, d, f)$. However, the electrospun mats had the greatest uniformity at a ratio of 70:30 (Figure 3f). Similar results were reported by Li et al. [32] that tested different blend solutions of the copolymer $\mathrm{P}(3 \mathrm{HB}-\mathrm{co}-3 \mathrm{HV})(25 \mathrm{~mol} \% \mathrm{HV}$ content) with the mcl-PHA $\mathrm{P}(\mathrm{HO}-\mathrm{co}-\mathrm{HHx})(92.6 \mathrm{~mol} \% \mathrm{HO}$ content) dissolved in a mixture of chloroform and DMF and obtained smooth, bead-free fibers from blend solutions at ratios above 65:35, with the greatest uniformity observed at a ratio of 75:25.

Together with $\mathrm{P}(3 \mathrm{HB})$ and $\mathrm{P}(3 \mathrm{HB}-\mathrm{co}-3 \mathrm{HV})$, the $\mathrm{P}(3 \mathrm{HB}-\mathrm{co}-3 \mathrm{HV})$ : mcl-PHA blend at a ratio of 70:30 was chosen for producing scaffolds, as indicated in Table 2, to be subject to the oxygen plasma treatment.

\subsubsection{Oxygen Plasma Treated Scaffolds}

The electrospun scaffolds obtained from $\mathrm{P}(3 \mathrm{HB}), \mathrm{P}(3 \mathrm{HB}-\mathrm{co}-3 \mathrm{HV})$ and $\mathrm{P}(3 \mathrm{HB}-\mathrm{co}-$ $3 \mathrm{HV}) / \mathrm{mcl}-\mathrm{PHA}$ blend solutions were exposed to oxygen plasma at a pressure of $100 \mathrm{mTorr}$ and a flow rate of $10 \mathrm{sccm}$. This treatment was tested as a surface modification method aiming to increase the scaffolds' hydrophilicity and, thus, facilitate cell adhesion. Plasma treatment with different fluids, including oxygen, nitrogen and carbon dioxide, were reported to render PHAs cast films more biocompatible by enhancing hydrophilicity and cell attachment $[35,37,53,54]$.

\subsection{Scaffolds Characterization}

\subsubsection{Morphology}

The electrospun $\mathrm{P}(3 \mathrm{HB}), \mathrm{P}(3 \mathrm{HB}-\mathrm{co}-3 \mathrm{HV})$ and $\mathrm{P}(3 \mathrm{HB}-\mathrm{co}-3 \mathrm{HV})$ : mcl-PHA scaffolds (Figure 4) were all similar in terms of texture, color and opacity, displaying a white and silky appearance and a thickness of $84 \pm 21,38 \pm 10$ and $39 \pm 2 \mu \mathrm{m}$, respectively. Treatment 
with oxygen plasma had no visible impact on the macroscopic structures but some distinct features could be identified by SEM analysis (Figure 5).
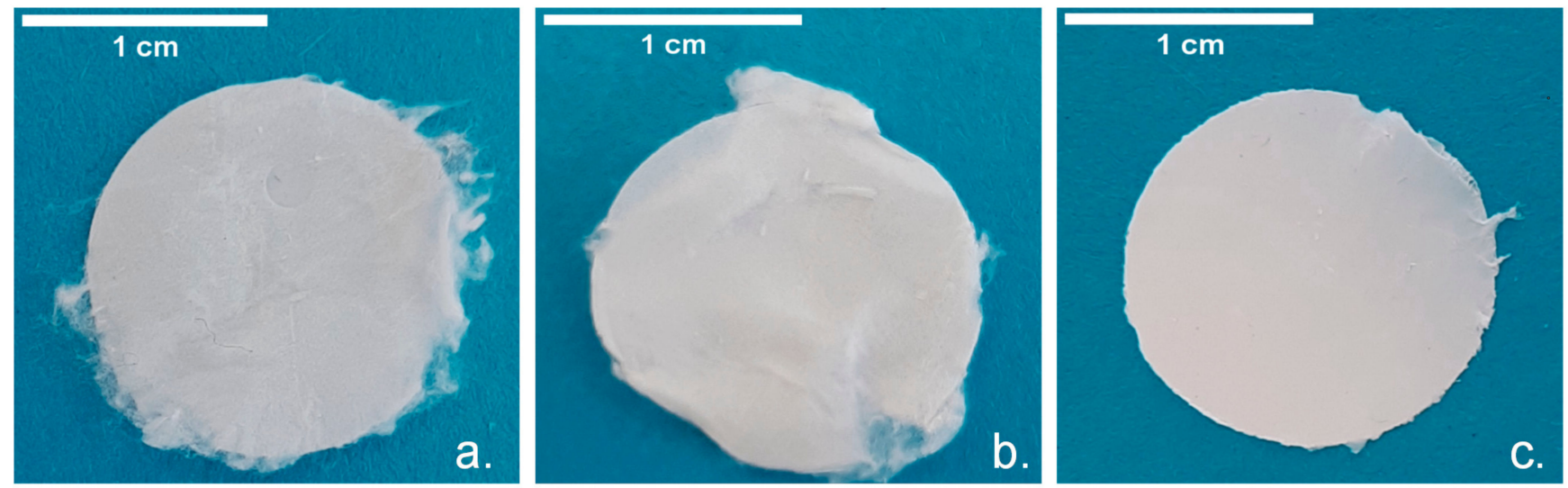

Figure 4. Electropsun (a) $\mathrm{P}(3 \mathrm{HB})$, (b) $\mathrm{P}(3 \mathrm{HB}-\mathrm{co}-3 \mathrm{HV})$ and (c) $\mathrm{P}(3 \mathrm{HB}-\mathrm{co}-3 \mathrm{HV})$ : mcl-PHA scaffolds.

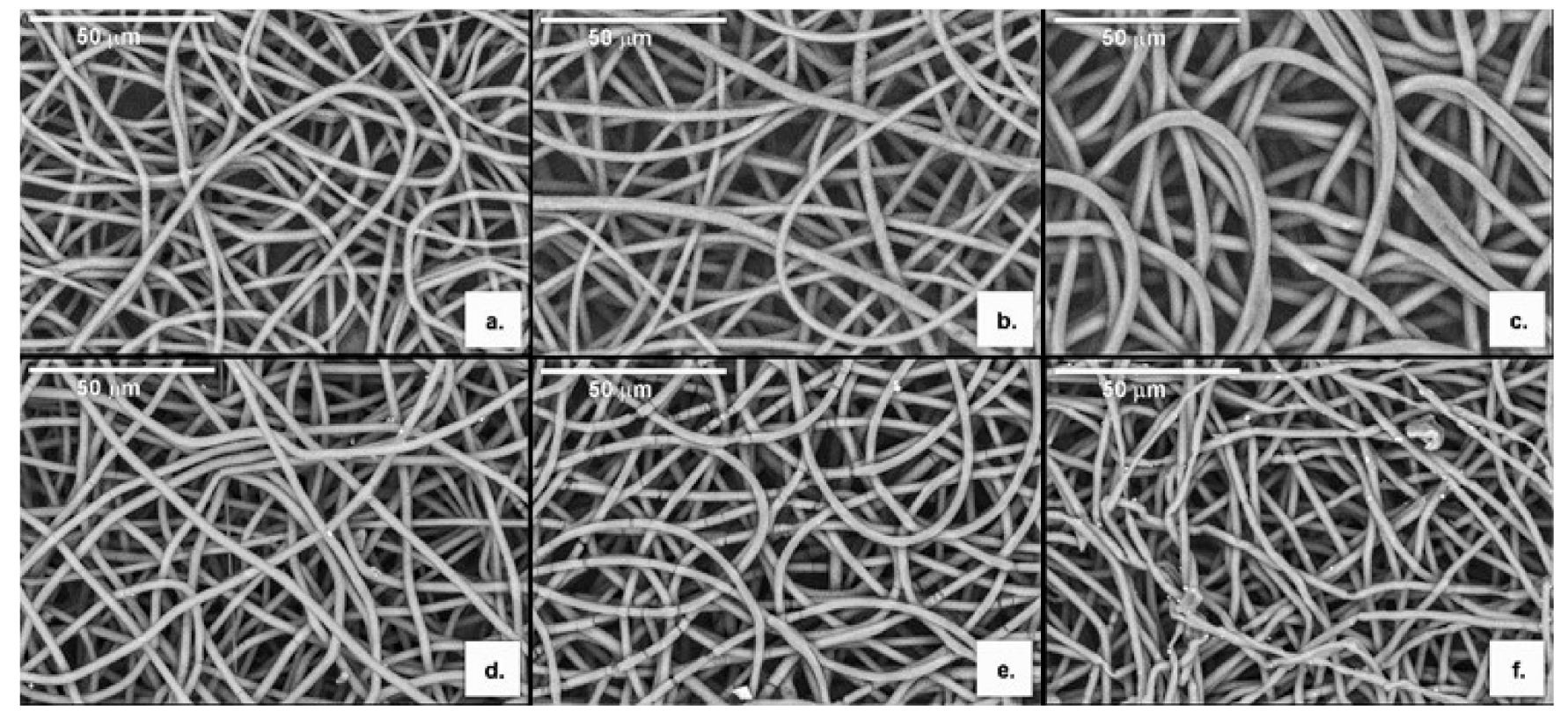

Figure 5. Images obtained by Scanning Electron Microscopy (SEM) analysis of the electrospun $\mathrm{P}(3 \mathrm{HB}), \mathrm{P}(3 \mathrm{HB}-\mathrm{co}-3 \mathrm{HV})$ and $\mathrm{P}(3 \mathrm{HB}-\mathrm{co}-3 \mathrm{HV})$ : mcl-PHA (70:30) blend scaffolds (a-c, respectively); SEM imaging of the electrospun fibers after $12 \mathrm{~min}$ of oxygen plasma exposure (d-f, respectively).

The SEM images of the electrospun $\mathrm{P}(3 \mathrm{HB}), \mathrm{P}(3 \mathrm{HB}-\mathrm{co}-3 \mathrm{HV})$ and $\mathrm{P}(3 \mathrm{HB}-\mathrm{co}-3 \mathrm{HV})$ : mclPHA scaffolds show that all present smooth, bead-less branched and randomly organized fibers with high void space interconnectivity (Figure 5). The diameter of at least 30 fibers of each scaffold was measured with ImageJ. The $\mathrm{P}(3 \mathrm{HB})$ scaffold (Figure 5a) presented fiber diameters of 1.7-3.4 $\mu \mathrm{m}$ and a mean diameter of $2.6 \pm 0.4 \mu \mathrm{m}$, while the $\mathrm{P}(3 \mathrm{HB}-\mathrm{co}-3 \mathrm{HV})$ microfibers (Figure 5b) had slightly larger dimensions, with diameters ranging between 2.1 and $3.5 \mu \mathrm{m}$, with a mean diameter of $2.7 \pm 0.4 \mu \mathrm{m}$. These values are comparable to that reported by Volova et al. [27] $(2.5 \mu \mathrm{m})$ for a for a $\mathrm{P}(3 \mathrm{HB}-\mathrm{co}-3 \mathrm{HV})$ with $4.5-8 \% 3 \mathrm{HV}$ content. Sombatmankhong et al. [26] also reported similar values $(2.3 \pm 2.1 \mu \mathrm{m})$ for a $\mathrm{P}\left(3 \mathrm{HB}-\mathrm{CO}_{-}\right.$ $3 \mathrm{HV})(5 \% 3 \mathrm{HV}$ content) electrospun scaffold but higher values for $\mathrm{P}(3 \mathrm{HB})$ electrospun fibers $(3.7 \pm 1.7 \mu \mathrm{m})$. On the other hand, Azari et al. [51] obtained $\mathrm{P}(3 \mathrm{HB})$ fibers of smaller dimensions $(1.3 \pm 0.3 \mu \mathrm{m})$. Nevertheless, these reported values are merely indicative since fiber diameter is dependent on electrospinning parameters (including solution parameters and processing parameters). The diameter of the fibers of the $\mathrm{P}(3 \mathrm{HB}-\mathrm{co}-3 \mathrm{HV})$ : mcl-PHA 
(70:30) blend scaffold (Figure 5c) is considerably higher than that in the scl-PHAs scaffolds, ranging between 3.6 and $4.6 \mu \mathrm{m}$, with a mean diameter of $4.0 \pm 0.2 \mu \mathrm{m}$. These values are significantly higher than those of the scl-/mcl-PHA electrospun scaffolds reported for fibers of $\mathrm{P}(3 \mathrm{HB}-\mathrm{co}-3 \mathrm{HV})(25 \mathrm{~mol} \% 3 \mathrm{HV}$ content) blended with $\mathrm{PHOHHx}(92.6 \mathrm{~mol} \% 3 \mathrm{HO})$ (0.48-0.76 $\mu \mathrm{m}$ range) [26] and for the blend of $\mathrm{P}(3 \mathrm{HB})$ with mcl-PHA $(0.81-1.31 \mu \mathrm{m})$ [52]. All the fibers obtained in the present study have a narrow size distribution, showing their size homogeneity.

After oxygen plasma exposure, alterations in the morphology of the fibers were noticed (Figure $5 \mathrm{~d}-\mathrm{f})$. Regarding the $\mathrm{P}(3 \mathrm{HB})$ and $\mathrm{P}(3 \mathrm{HB}-\mathrm{co}-3 \mathrm{HV})$ scaffolds, fractures along the fibers are visible (Figure 5d,e), especially in the copolymer scaffold, for which a higher number of said fractures is observed (Figure 5e). The fibers' mean diameter was not affected in the $\mathrm{P}(3 \mathrm{HB})$ scaffold, remaining the same after treatment $(2.6 \pm 0.5 \mu \mathrm{m})$, despite of a slight increase of their size distribution (1.4-3.6 $\mu \mathrm{m})$. In contrast, a decrease in mean fiber diameter from $2.7 \pm 0.4$ to $2.2 \pm 0.5 \mu \mathrm{m}$ was observed for the $\mathrm{P}(3 \mathrm{HB}-\mathrm{co}-3 \mathrm{HV})$ scaffold and thinner fibers were also observed, with a wider fiber size distribution $(1.1-3.5 \mu \mathrm{m})$. The fibers of the P(3HB-co-3HV): mcl-PHA scaffold, on the other hand, did not seem to suffer for much fracturing (Figure 3f), although a slight thinning was evidenced with a decrease in the fiber mean diameter from $4.0 \pm 0.2$ to $2.6 \pm 0.2 \mu \mathrm{m}$. There was also a considerable broadening of the fibers size distribution $(1.2-3.6 \mu \mathrm{m})$. These results show that subjecting the scaffolds to plasma treatment impacted the fibers homogeneity, which may be explained by the physical etching phenomena, where the ions in the plasma cause erosion of the material [36]. Nevertheless, the thinning of the fibers corresponded to an increase of the surface area, which might turn beneficial for promoting cell attachment $[55,56]$.

Regarding the scaffolds' porosity, no significant changes were noticed for the average pore size of the oxygen plasma treated scaffolds compared to the electropsun scaffolds (Table 3).

Table 3. Water contact angles and water uptake degree of the scaffolds fabricated with $\mathrm{P}(3 \mathrm{HB})$, $\mathrm{P}(3 \mathrm{HB}-\mathrm{co}-3 \mathrm{HV})$ and $\mathrm{P}(3 \mathrm{HB}-\mathrm{co}-3 \mathrm{HV})$ : mcl-PHA blends.

\begin{tabular}{|c|c|c|c|}
\hline Processing/Scaffold & Pore Size $(\mu \mathrm{m})$ & Water Contact Angle $(\theta)$ & Water Uptake Degree (\%) \\
\hline \multicolumn{4}{|c|}{ Electrospinning } \\
\hline $\mathrm{P}(3 \mathrm{HB})$ & $9.4 \pm 3.5$ & $84.3 \pm 1.8$ & 0 \\
\hline $\mathrm{P}(3 \mathrm{HB}-c o-3 \mathrm{HV})$ & $10.2 \pm 2.7$ & $96.8 \pm 1.3$ & 77 \\
\hline $\begin{array}{l}\text { P(3HB-co-3HV): } \\
\text { mcl-PHA blend }\end{array}$ & $10.2 \pm 3.3$ & $113.5 \pm 0.7$ & 0 \\
\hline \multicolumn{4}{|c|}{ Electrospinning $+\mathrm{O}_{2}$ Plasma Treatment } \\
\hline $\mathrm{P}(3 \mathrm{HB})$ & $10.0 \pm 2.9$ & 0 & 294 \\
\hline $\mathrm{P}(3 \mathrm{HB}-\mathrm{co}-3 \mathrm{HV})$ & $9.5 \pm 2.5$ & 0 & 205 \\
\hline $\begin{array}{l}\mathrm{P}(3 \mathrm{HB}-\mathrm{co}-3 \mathrm{HV}) \\
\text { mcl-PHA blend }\end{array}$ & $10.4 \pm 3.4$ & 0 & 17 \\
\hline
\end{tabular}

\subsubsection{Molecular Mass Distribution}

A slight decrease of the biopolymers' $M_{w}$ upon exposure to the electrospinning conditions has been also observed (Table 1$)$. The $\mathrm{M}_{\mathrm{W}}$ of the $\mathrm{P}(3 \mathrm{HB})$ electrospun fibers was $4.20 \times 10^{5} \mathrm{Da}$, compared to $5.20 \times 10^{5} \mathrm{Da}$ of the raw biopolymer. Similarly, the $\mathrm{M}_{\mathrm{W}}$ of the $\mathrm{P}(3 \mathrm{HB}-\mathrm{CO}-3 \mathrm{HV})$ fibers showed a similar decrease from $5.60 \times 10^{5} \mathrm{Da}$ to $4.10 \times 10^{5} \mathrm{Da}$. This drop in $\mathrm{M}_{\mathrm{W}}$ of these aliphatic polyesters can be assigned to a partial hydrolysis of their ester bonds during the fabrication process and/or their storage. Interestingly, the biopolymer PDI was not significantly affected during electrospinning (Table 1). Exposure of the P(3HB) and $\mathrm{P}(3 \mathrm{HB}-\mathrm{co}-3 \mathrm{HV})$ scaffolds to oxygen plasma seems to provoke a further decrease in the biopolymers' $\mathrm{M}_{\mathrm{w}}$ but with an increase in PDI (Table 1). The $\mathrm{M}_{\mathrm{w}}$ was reduced from $4.20 \times 10^{5}$ and $4.10 \times 10^{5} \mathrm{Da}$, respectively, to $3.50 \times 10^{5} \mathrm{Da}$, while their PDI increased from $1.63-1.69$ to $1.90-2.00$. This increase in polydispersity can be explained by the surface 
character of plasma exposure. Indeed, polymer chains present at the surface of the fibers should be more prompted to hydrolysis than polymer chains embedded in their core.

An average $\mathrm{M}_{\mathrm{w}}$ of $3.50 \times 10^{5}$ Da was observed for the $\mathrm{P}(3 \mathrm{HB}-\mathrm{co}-3 \mathrm{HV})$ and mcl-PHA in the blend fibers (Table 1). This value is within the those obtained for the copolymer's fibers $\left(4.10 \times 10^{5} \mathrm{Da}\right)$ and those of the mcl-PHA $\left(0.69 \times 10^{5} \mathrm{Da}\right)$. On the other hand, the PDI was higher than either biopolymer, 2.79 (Table 1), reflecting the higher size dispersity of the two biopolymer molecules present in the blend. Contrary to the scl-PHAs scaffolds, no reduction of the $\mathrm{M}_{\mathrm{w}}$ was observed for the oxygen plasma treated $\mathrm{P}(3 \mathrm{HB}-\mathrm{co}-3 \mathrm{HV})$ : mcl-PHA scaffolds and the PDI was only slightly increased from 2.8 to 2.9 , suggesting that the PHA blend was more resistant to depolymerization by exposure to oxygen plasma than the single scl-PHA-based materials.

\subsubsection{Thermal Properties}

The biopolymers' thermal properties were not significantly changed after processing into microfibers nor more than by exposure to oxygen plasma (Table 1). For both $\mathrm{P}(3 \mathrm{HB})$ and $\mathrm{P}(3 \mathrm{HB}-\mathrm{co}-3 \mathrm{HV})$ electrospun scaffolds, only a slight decrease of their $T_{m}$, from 176 to $173^{\circ} \mathrm{C}$ and from 173 to $167^{\circ} \mathrm{C}$, respectively, was noticed compared to the raw materials. Their subsequent oxygen plasma treatment did not cause any further decease (Table 1 ). This reduction in $T_{m}$ can be correlated to the $\mathrm{M}_{\mathrm{W}}$ decline and differences in crystallinity observed after processing by electrospinning [20]. The lower $T_{m}$ of crystals made from lowermolecular-weight polymers can be explained by their higher content in chain ends [57]. Interestingly, the $T_{d e g}$ was not altered either after electrospinning, either after oxygen plasma exposure, all samples displaying values within $288-293{ }^{\circ} \mathrm{C}$ (Table 1 ).

A slight increase of the $\Delta H_{m}$ and the $X_{c}$ were noticed for the scl-PHAs scaffolds compared to the unprocessed biopolymers (Table 1). The $\Delta H_{m}$ increased from 76.5 to $77.5 \mathrm{~J} \mathrm{~g}^{-1}$, for the electrospun $\mathrm{P}(3 \mathrm{HB})$ scaffold and from 34.5 to $36.1 \mathrm{~J} \mathrm{~g}^{-1}$, for the electrospun $\mathrm{P}(3 \mathrm{HB}-$ co-3HV) scaffold. Concomitantly, the $X_{c}$ increased from $52.4 \%$ to $53.1 \%$ and from $23.6 \%$ to $24.7 \%$, for the homopolymer and the copolymer, respectively. The rise in crystallinity can be attributed to the orientation of macromolecular chains in the longitudinal fiber direction during the electrospinning process, that may have promoted crystallization [58]. On the other hand, exposure to oxygen plasma had a much more relevant impact on the biopolymers, as shown by the considerably lower $\Delta H_{m}$ and $X_{c}$ values (Table 1). These results demonstrate that the treatment led to more exposed amorphous phases in the biopolymers.

For the $\mathrm{P}(3 \mathrm{HB}-\mathrm{co}-3 \mathrm{HV})$ : mcl-PHA blend, two melting temperatures $\left(169\right.$ and $\left.46^{\circ} \mathrm{C}\right)$ were detected (Table 1$)$, one corresponding to the $T_{m}$ of $\mathrm{P}(3 \mathrm{HB}-\mathrm{co}-3 \mathrm{HV})$ and the other to the $T_{m}$ of the mcl-PHA in the composite, demonstrating a successful blend development. The degradation temperature $\left(290^{\circ} \mathrm{C}\right)$ (Table 1$)$ was close to the value for unprocessed mcl-PHA and $\mathrm{P}(3 \mathrm{HB}-\mathrm{co}-3 \mathrm{HV})$ (both $292^{\circ} \mathrm{C}$ ).

\subsubsection{Water Contact Angle and Water Uptake Degree}

The $\mathrm{P}(3 \mathrm{HB}-\mathrm{co}-3 \mathrm{HV})$ and the scl-/mcl-PHA electrospun scaffolds presented water contact angles of $96.8 \pm 1.3^{\circ}$ and $113.5 \pm 0.7^{\circ}$, respectively (Table 3 ), which demonstrates their hydrophobicity. On the other hand, the $\mathrm{P}(3 \mathrm{HB})$ electrospun scaffold was hydrophilic, given its water contact angle $\left(84.3 \pm 1.8^{\circ}\right)$ was below $90^{\circ}$ [59]. The images of water droplets used for contact angle measurements are shown in Figure 6. Water contact angles in the range $115-126^{\circ}$ have been reported for PHA-based electrospun scaffolds, including $\mathrm{P}(3 \mathrm{HB})$, $\mathrm{P}(3 \mathrm{HB}-\mathrm{co}-3 \mathrm{HV})$ and their blends $[26,60]$. The lower values observed for the $\mathrm{P}(3 \mathrm{HB})$ and $\mathrm{P}(3 \mathrm{HB}-\mathrm{co}-3 \mathrm{HV})$ scaffolds may be related to the higher surface roughness of the produced microfiber meshes that lead to a decrease of the water drop-material contact area, thus increasing the water contact angle of the materials [61].

After exposure to oxygen plasma, all three scaffolds experienced complete wetting $\left(\theta=0^{\circ}\right)$ (Table 3), thus showing that they were highly hydrophilic. It was not possible to collect images of water droplets because they were immediately absorbed by the scaffolds. The hydrophilic nature of the treated scaffolds was confirmed by measuring their water 
uptake degree (Table 3). Interestingly, the $\mathrm{P}(3 \mathrm{HB})$ electrospun scaffold, which had no water uptake, displayed a water uptake degree of $294 \%$ after the oxygen plasma treatment. The water uptake degree of the $\mathrm{P}(3 \mathrm{HB}-\mathrm{co}-3 \mathrm{HV})$ scaffold also increased significantly upon exposure to oxygen plasma, from $77 \%$ to $205 \%$. Although there was a change in mass due to water absorption, there was no changes in scaffold thickness or shape. Blending the copolymer with the mcl-PHA reduced the scaffolds ability to uptake water. Indeed, $0 \%$ water uptake degree was noticed on the $\mathrm{P}(3 \mathrm{HB}-\mathrm{co}-3 \mathrm{HV})$ : mcl-PHA scaffold, compared to the $\mathrm{P}(3 \mathrm{HB}-\mathrm{co}-3 \mathrm{HV})$ scaffold $(77 \%)$. This represents an increase of $17 \%$ after exposure to oxygen plasma, which was nevertheless still significantly lower than the value found for the treated copolymer scaffold (205\%). Overall, the oxygen plasma treatment proved to not only enhance surface hydrophilicity and, therefore, facilitate also water diffusion, which is crucial for 3D-cell culture scaffolds.

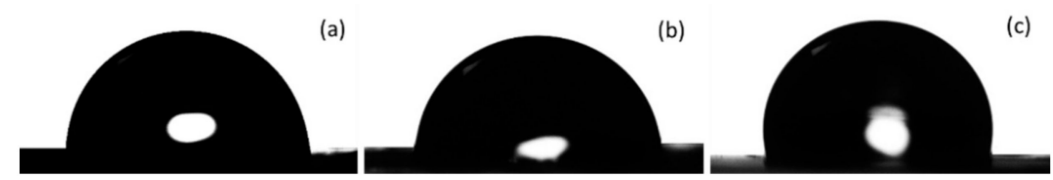

Figure 6. Images of the water droplets used for contact angle measurements of the electrospun scaffolds: (a) $\mathrm{P}(3 \mathrm{HB}),(\mathbf{b}) \mathrm{P}(3 \mathrm{HB}-\mathrm{co}-3 \mathrm{HV})$ and (c) $\mathrm{P}(3 \mathrm{HB}-\mathrm{co}-3 \mathrm{HV})$ : mcl-PHA blend.

\subsubsection{Fourier Transform Infrared Spectroscopy}

The FT-IR spectra for the biopolymers and the corresponding electrospun scaffolds are shown in Figure 7. In all spectra, an intense peak can be observed at around $1720-1750 \mathrm{~cm}^{-1}$, corresponding to the stretching band of the ester carbonyl group [62]. The bands between around 960 and $1280 \mathrm{~cm}^{-1}$, which are related to the degree of crystallinity, are significantly more intense for $\mathrm{P}(3 \mathrm{HB})$ and $\mathrm{P}(3 \mathrm{HB}-\mathrm{co}-3 \mathrm{HV})$ ) than for the mcl-PHA, in accordance with the biopolymers crystallinity degree $(52.4 \%$ and $23.6 \%$, for the scl-PHAs, respectively and $5.6 \%$ for the mcl-PHA) (Table 1). On the other hand, the bands near 2961-2854 $\mathrm{cm}^{-1}$ that correspond to the asymmetric $\mathrm{CH}_{2}$ of the lateral monomeric chains (the peak near $2924 \mathrm{~cm}^{-1}$ ), the methylene C-H elongation vibration (the peak near $2900 \mathrm{~cm}^{-1}$ ) and the symmetrical methyl group (the peak near $2847 \mathrm{~cm}^{-1}$ ) [63], are stronger for the mcl-PHA and weaker for the scl-PHAs. A peak near $800 \mathrm{~cm}^{-1}$ is also noticed in the mcl-PHA spectrum but not on the scl-PHAs spectra (Figure 7). The FTIR spectrum for the P(3HB-co-3HV): mcl-PHA blend combine the characteristic peaks for the co-polymer and the mcl-PHA.

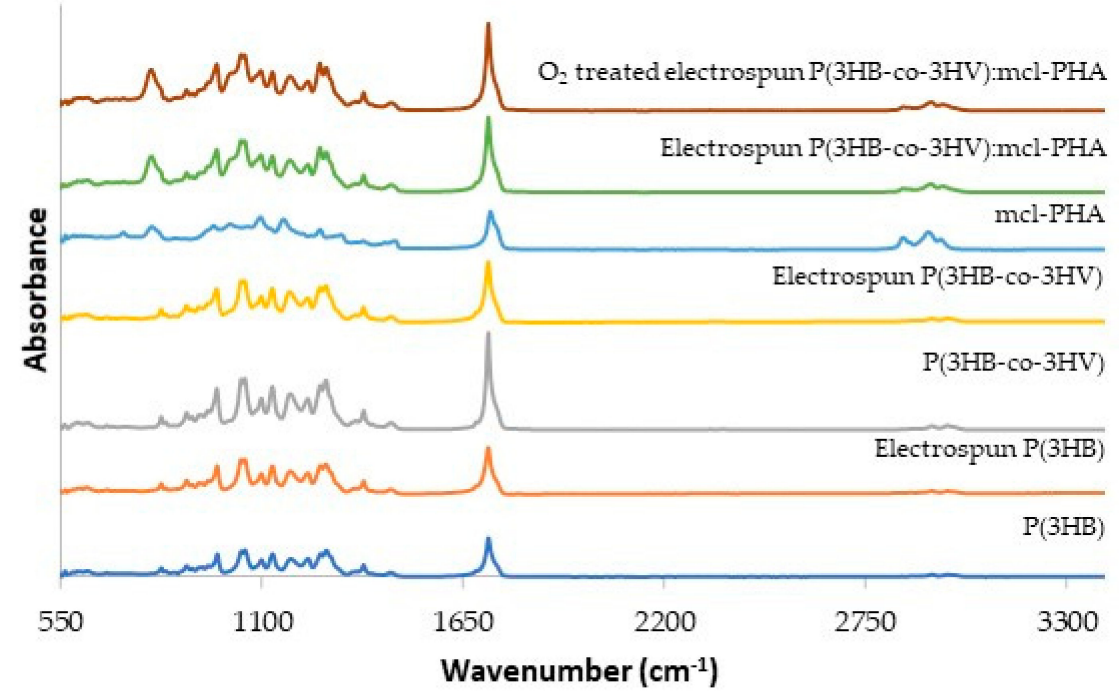

Figure 7. FTIR-ATR spectra of the biopolymers $\mathrm{P}(3 \mathrm{HB}), \mathrm{P}(3 \mathrm{HB}-\mathrm{co}-3 \mathrm{HV})$ and the mcl-PHA, of the electrospun scaffolds made of $\mathrm{P}(3 \mathrm{HB}), \mathrm{P}(3 \mathrm{HB}-\mathrm{co}-3 \mathrm{HV})$ and the $\mathrm{P}(3 \mathrm{HB}-\mathrm{co}-3 \mathrm{HV})$ : mcl-PHA blend and of the oxygen plasma treated $\mathrm{P}(3 \mathrm{HB}-\mathrm{co}-3 \mathrm{HV})$ : mcl-PHA blend scaffold. 
Processing the biopolymers into electrospun fibers and, afterwards, subjecting them to oxygen plasma treatment, had no significant impact on the spectra as all the characteristic peaks were retained, with no relevant change in intensity (Figure 7).

\subsection{Biological Assays}

\subsubsection{Cell Viability}

In order to assess the scaffolds functionality and biocompatibility, human dermal fibroblasts (HDFn) colonization, adhesion and viability were studied using the MTT assay on the electrospun meshes made from $\mathrm{P}(3 \mathrm{HB}), \mathrm{P}(3 \mathrm{HB}-\mathrm{co}-3 \mathrm{HV})$ and $\mathrm{P}(3 \mathrm{HB}-\mathrm{co}-3 \mathrm{HV})$ : mclPHA blend. As positive control, a commercial polystyrene scaffold (Alvetex ${ }^{\mathrm{TM}}$ ) commonly used for 3D cell culture of mammalian cells [64-66], was used as a reference.

Three independent assays were carried out with HDFns of different passage for reproducibility purposes. Polystyrene wells were also used as additional positive control and referred as $100 \%$ attachment. A ratio between the absorbance of each scaffold and the control was calculated for every trial and then the average between all trials, as well as standard deviation was calculated (Figure 8). One-way ANOVA statistical method was utilized to compare the viability of HDFns cultured onto the different scaffolds and the results proved to be statistically significant $(p<0.05)$ with a $p$-value of 0.01 .

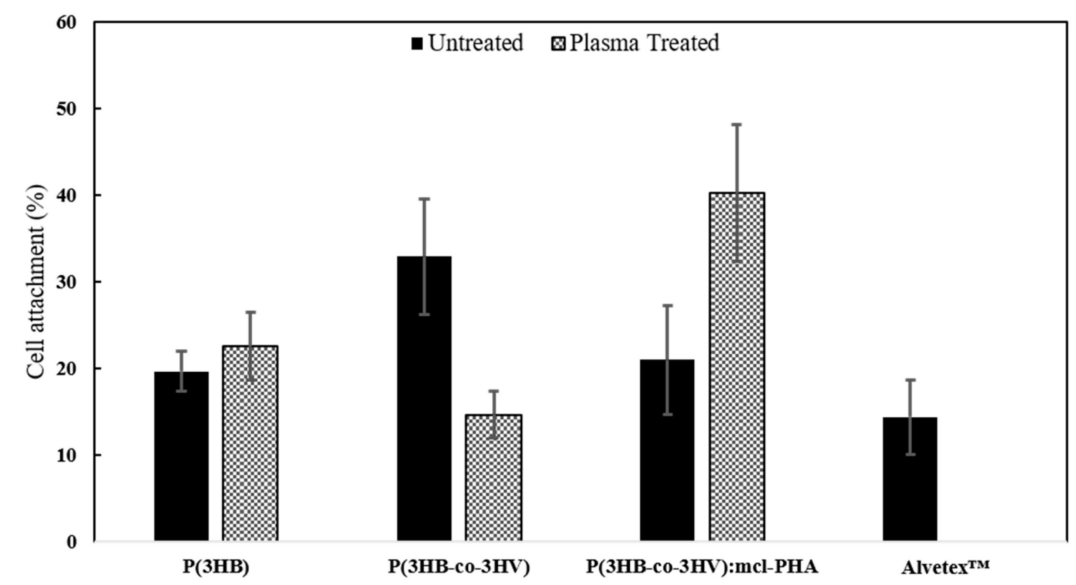

Figure 8. Comparison of the HDFns adhesion on different types of PHA based scaffolds with and without oxygen plasma treatment, measured by MTT assay. A commercial 3D mesh, Alvetex ${ }^{\mathrm{TM}}$, has been used as reference. The cell attachment values are the ratio between the absorbance of each sample and the attachment attained in polystyrene wells.

Exception made of the electrospun $\mathrm{P}(3 \mathrm{HB}-\mathrm{co}-3 \mathrm{HV})$ plasma treated scaffold, which disclosed similar cell density $(15 \pm 3 \%)$ to Alvatex $^{\mathrm{TM}}(14 \pm 4 \%)$, all other polyester meshes (plasma treated and untreated) presented superior cell attachment values (Figure 4). The higher cell density values were noticed for the plasma treated $\mathrm{P}(3 \mathrm{HB}-\mathrm{co}-3 \mathrm{HV})$ : mcl-PHA and the untreated $\mathrm{P}(3 \mathrm{HB}-\mathrm{Co}-3 \mathrm{HV})$ scaffolds, whit improved cell attachment 2.8-fold and 2.3-fold. It is worth mentioning that the oxygen plasma treatment affected differently each scaffold. The homopolymer scaffold's cell attachment only improved slightly upon the treatment, from $19.6 \pm 2.3 \%$ to $22.5 \pm 4.0 \%$, while that of the P(3HB-co-3HV): mcl-PHA scaffold doubled its values (from $20.9 \pm 6.3 \%$ to $40.2 \pm 7.9 \%$ ). For the P(3HB-co-3HV), on the other hand, a contrasting behavior was observed: the plasma treatment caused a reduction of cell attachment from $32.9 \pm 6.6 \%$ to $14.6 \pm 2.6 \%$.

The lower values observed for the treated $\mathrm{P}(3 \mathrm{HB}-\mathrm{co}-3 \mathrm{HV})$ scaffold may be related to the damage noted in the fibers (revealed by SEM) after exposure to oxygen plasma (Figure 3e) that might have negatively impacted cell attachment, fiber heterogeneity has been reported to cause lower attachment of NIH 3 T3 fibroblasts [55]. The P(3HB-co-3HV): mcl-PHA blend's higher attachment after oxygen plasma treatment can be related to both increased surface hydrophilicity and thinning of the fibers. Thinner fibers have augmented 
surface area for adsorption of extracellular matrix proteins that interact with anchorage dependent mammalian cells and lead to improved attachment [67]. MG-63 cells and NIH 3T3 fibroblasts have shown superior attachment to smaller diameter fibers of biomaterials when compared to their larger diameter counterparts $[56,68]$.

\subsubsection{Cell Morphology}

The cells' morphology on the different scaffolds was observed under SEM. Noticeable cell attachment was observed for all fibrous scaffolds (Figure 9), proving them to be a favorable environment for cell adhesion and confirming MTT results. The fibroblasts present already an elongation of their shape in direction of the fiber axis stretching to adhesion points on adjacent fibers. This cell behavior is similar to other observations reported earlier involving fibroblast culture onto electrospun fibers, for example for mouse fibroblast cells (L929) cultured onto a P(3HB)/silk fibroin composite nanofiber mats [69].
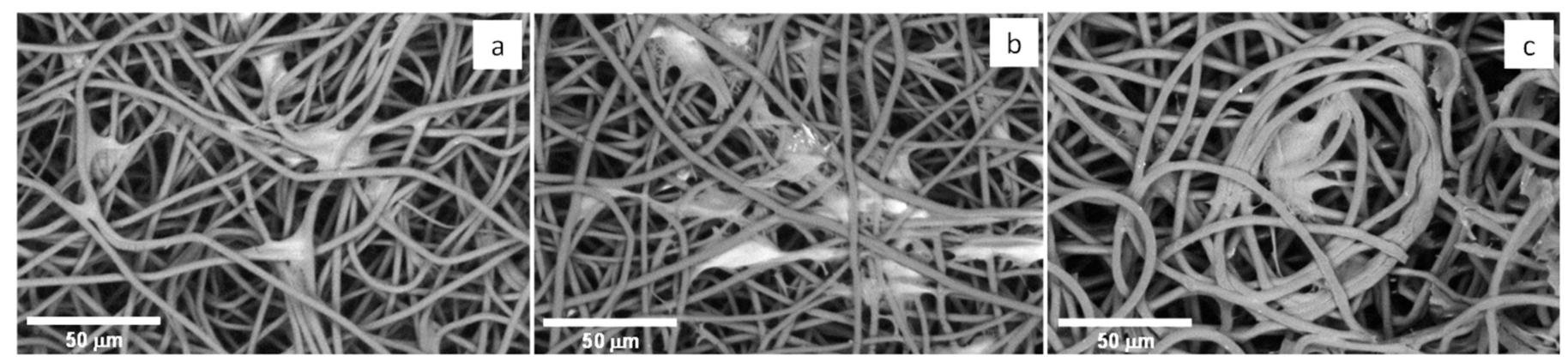

Figure 9. SEM images of HDFn attached to PHA-based electrospun scaffolds: (a) $\mathrm{P}(3 \mathrm{HB}),(\mathbf{b}) \mathrm{P}(3 \mathrm{HB}-\mathrm{co}-3 \mathrm{HV})$ and (c) $\mathrm{P}(3 \mathrm{HB}-$ co-3HV): mcl-PHA.

\section{Conclusions}

This study demonstrated the suitability of the biopolyesters $\mathrm{P}(3 \mathrm{HB}), \mathrm{P}(3 \mathrm{HB}-\mathrm{co}-3 \mathrm{HV})$ and an mcl-PHA for the preparation of electrospun scaffolds based with improved hydrophilicity and cell adhesion by exposure to oxygen plasma. The developed scaffolds possessed a porous structure, with interconnected pores and were hydrophilic. All scaffolds were biocompatible and provided an appropriate structure for cell adhesion. The most promising result was achieved for the oxygen plasma treated electropsun $\mathrm{P}(3 \mathrm{HB}-\mathrm{co}-3 \mathrm{HV})$ : mcl-PHA blend scaffold, which displayed considerably higher cell attachment than the commercial synthetic material. Therefore, these original results encourage the future investigations on plasma treatment as a technique for developing hydrophilic electrospun scaffolds $\mathrm{P}(3 \mathrm{HB}-\mathrm{co}-3 \mathrm{HV})$ : mcl-PHA scaffolds. Such biocompatible structures may find application in the development of 3D in vitro cell models, as well as for their consideration as degradable and biocompatible scaffold for tissue engineering applications.

Author Contributions: Conceptualization, A.E., A.O. and F.F.; Formal analysis, A.E. and F.F.; Investigation, A.E.; Methodology, A.E., J.R.P., P.Z., S.S., U.D.M. and C.S.; Writing-original draft, A.E. and F.F.; Writing-review and editing, C.G., E.F., M.A.M.R., C.H., A.O. and F.F. All authors have read and agreed to the published version of the manuscript.

Funding: Please add: This research was funded by FCT I.P., through the Research Unit on Applied Molecular Biosciences (UCIBIO) (UIDP/04378/2020 and UIDB/04378/2020), the Instituto de Tecnologia Química e Biológica António Xavier (ITQB NOVA) (iNOVA4Health/MULTI/04462/2018) and Materials Research Center from the Associate Laboratory (UIDB/50025/2020). J.P. acknowledges FCT I.P. for Grant SFRH/BD/147518/2019.

Institutional Review Board Statement: Not applicable.

Informed Consent Statement: Not applicable. 
Data Availability Statement: The data presented in this study are available on request from the corresponding author.

Conflicts of Interest: The authors declare no conflict of interest.

\section{References}

1. Zubairi, S.I.; Mantalaris, A.; Bismarck, A.; Aizad, S. Polyhydroxyalkanoates (PHAs) for tissue engineering applications: Biotransformation of palm oil mill effluent (POME) to value-added polymers. J. Teknol. 2016, 78, 13-29. [CrossRef]

2. Huh, D.; Hamilton, G.A.; Ingber, D.E. From 3D cell culture to organs-on-chips. Trends Cell Biol. 2011, 21, 745-754. [CrossRef]

3. Bédard, P.; Gauvin, S.; Ferland, K.; Caneparo, C.; Pellerin, È; Chabaud, S.; Bolduc, S. Innovative Human Three-Dimensional Tissue-Engineered Models as an Alternative to Animal Testing. Bioengineering 2020, 7, 115. [CrossRef] [PubMed]

4. Trepat, X.; Chen, Z.; Jacobson, K. Cell Migration. Compr. Physiol. 2012, 2, 2369-2392. [CrossRef]

5. Wang, L.; Wang, C.; Wu, S.; Fan, Y.; Li, X. Influence of the mechanical properties of biomaterials on degradability, cell behaviors and signaling pathways: Current progress and challenges. Biomater. Sci. 2020, 8, 2714-2733. [CrossRef]

6. Wimmer, R.A.; Leopoldi, A.; Aichinger, M.; Wick, N.; Hantusch, B.; Novatchkova, M.; Taubenschmid, J.; Hämmerle, M.; Esk, C.; Bagley, J.A.; et al. Human blood vessel organoids as a model of diabetic vasculopathy. Nat. Cell Biol. 2019, 565, 505-510. [CrossRef] [PubMed]

7. Lee, V.; Singh, G.; Trasatti, J.P.; Bjornsson, C.; Xu, X.; Tran, T.N.; Yoo, S.-S.; Dai, G.; Karande, P. Design and Fabrication of Human Skin by Three-Dimensional Bioprinting. Tissue Eng. Part C Methods 2014, 20, 473-484. [CrossRef] [PubMed]

8. Yan, Y.; Chen, H.; Zhang, H.; Guo, C.; Yang, K.; Chen, K.; Cheng, R.; Qian, N.; Sandler, N.; Zhang, Y.S.; et al. Vascularized 3D printed scaffolds for promoting bone regeneration. Biomaterials 2019, 190-191, 97-110. [CrossRef]

9. Pusch, J.; Votteler, M.; Göhler, S.; Engl, J.; Hampel, M.; Walles, H.; Schenke-Layland, K. The physiological performance of a three-dimensional model that mimics the microenvironment of the small intestine. Biomaterials 2011, 32, 7469-7478. [CrossRef]

10. Campuzano, S.; Pelling, A.E. Scaffolds for 3D Cell Culture and Cellular Agriculture Applications Derived From Non-animal Sources. Front. Sustain. Food Syst. 2019, 3, 38. [CrossRef]

11. Deluzio, T.G.; Seifu, D.G.; Mequanint, K. 3D scaffolds in tissue engineering and regenerative medicine: Beyond structural templates? Pharm. Bioprocess. 2013, 1, 267-281. [CrossRef]

12. Engler, A.J.; Sen, S.; Sweeney, H.L.; Discher, D.E. Matrix Elasticity Directs Stem Cell Lineage Specification. Cell 2006, 126, 677-689. [CrossRef] [PubMed]

13. Hayward, A.S.; Sano, N.; Przyborski, S.A.; Cameron, N.R. Acrylic-Acid-Functionalized PolyHIPE Scaffolds for Use in 3D Cell Culture. Macromol. Rapid Commun. 2013, 34, 1844-1849. [CrossRef]

14. Możejko-Ciesielska, J.; Kiewisz, R. Bacterial polyhydroxyalkanoates: Still fabulous? Microbiol. Res. 2016, 192, 271-282. [CrossRef] [PubMed]

15. Liu, Q.; Zhang, H.; Deng, B.; Zhao, X. Poly(3-hydroxybutyrate) and Poly(3-hydroxybutyrate-co-3-hydroxyvalerate): Structure, Property, and Fiber. Int. J. Polym. Sci. 2014, 2014, 374368. [CrossRef]

16. Radu, I.C.; Hudita, A.; Zaharia, C.; Galateanu, B.; Iovu, H.; Vasile, E.; Nitu, S.G.; Ginghina, O.; Negrei, C.; Tsatsakis, A.; et al. Poly(3-hydroxybutyrate-CO-3-hydroxyvalerate) PHBHV biocompatible nanocarriers for 5-FU delivery targeting colorectal cancer. Drug Deliv. 2019, 26, 318-327. [CrossRef] [PubMed]

17. Basnett, P.; Marcello, E.; Lukasiewicz, B.; Panchal, B.; Nigmatullin, R.; Knowles, J.C.; Roy, I. Biosynthesis and characterization of a novel, biocompatible medium chain length polyhydroxyalkanoate by Pseudomonas mendocina $\mathrm{CH} 50$ using coconut oil as the carbon source. J. Mater. Sci. Mater. Med. 2018, 29, 179. [CrossRef] [PubMed]

18. Knight, E.; Przyborski, S. Advances in 3D cell culture technologies enabling tissue-like structures to be created in vitro. J. Anat. 2015, 227, 746-756. [CrossRef]

19. Xu, C.; Inai, R.; Kotaki, M.; Ramakrishna, S. Aligned biodegradable nanofibrous structure: A potential scaffold for blood vessel engineering. Biomaterials 2004, 25, 877-886. [CrossRef]

20. Vieira, T.; Silva, J.C.; Botelho do Rego, A.M. Electrospun biodegradable chitosan based-poly(urethane urea)scaffolds for soft tissue engineering. Mater. Sci. Eng. C 2019, 103, 109819. [CrossRef]

21. Tan, D.; Yin, J.; Chen, G.Q. Production of Polyhydroxyalkanoates. In Current Developments in Biotechnologyand Bioengineering, Production, Isolation and Purification of Industrial Products; Pandey, A., Negi, S., Soccol, C.R., Eds.; Elsevier: Amsterdam, The Netherlands, 2017; pp. 655-692. ISBN 978-0-444-6366.

22. Silva, J.; Pereira, J.; Marreiros, B.; Reis, M.; Freitas, F. Microbial production of medium-chain length polyhydroxyalkanoates. Proc. Biochem. 2021, 102, 393-407. [CrossRef]

23. Anjum, A.; Zuber, M.; Zia, K.M.; Noreen, A.; Anjum, M.N.; Tabasum, S. Microbial production of polyhydroxyalkanoates (PHAs) and its copolymers: A review of recent advancements. Int. J. Biol. Macromol. 2016, 89, 161-174. [CrossRef]

24. Sangsanoh, P.; Waleetorncheepsawat, S.; Suwantong, O.; Wutticharoenmongkol, P.; Weeranantanapan, O.; Chuenjitbuntaworn, B.; Cheepsunthorn, P.; Pavasant, A.P.; Supaphol, P. In Vitro Biocompatibility of Schwann Cells on Surfaces of Biocompatible Polymeric Electrospun Fibrous and Solution-Cast Film Scaffolds. Biomacromolecules 2007, 8, 1587-1594. [CrossRef] [PubMed]

25. Meereboer, K.W.; Misra, M.; Mohanty, A.K. Review of recent advances in the biodegradability of polyhydroxyalkanoate (PHA) bioplastics and their composites. Green Chem. 2020, 22, 5519-5558. [CrossRef] 
26. Sombatmankhong, K.; Suwantong, O.; Waleetorncheepsawat, S.; Supaphol, P. Electrospun fiber mats of poly(3-hydroxybutyrate), poly(3-hydroxybutyrate-co-3-hydroxyvalerate), and their blends. J. Polym. Sci. Part B Polym. Phys. 2006, 44, 2923-2933. [CrossRef]

27. Volova, T.; Goncharov, D.; Sukovatyi, A.; Shabanov, A.; Nikolaeva, E.; Shishatskaya, E. Electrospinning of polyhydroxyalkanoate fibrous scaffolds: Effects on electrospinning parameters on structure and properties. J. Biomater. Sci. Polym. Ed. 2013, 25, 370-393. [CrossRef]

28. Cheng, M.-L.; Chen, P.-Y.; Lan, C.-H.; Sun, Y.-M. Structure, mechanical properties and degradation behaviors of the electrospun fibrous blends of phbhhx/pdlla. Polymer 2011, 52, 139-140. [CrossRef]

29. Canadas, R.F.; Cavalheiro, J.M.; Guerreiro, J.D.; De Almeida, M.C.M.; Pollet, E.; Da Silva, C.L.; Da Fonseca, M.; Ferreira, F.C. Polyhydroxyalkanoates: Waste glycerol upgrade into electrospun fibrous scaffolds for stem cells culture. Int. J. Biol. Macromol. 2014, 71, 131-140. [CrossRef] [PubMed]

30. Zhang, S.; Prabhakaran, M.P.; Qin, X.; Ramakrishna, S. Poly-3-hydroxybutyrate-co-3-hydroxyvalerate containing scaffolds and their integration with osteoblasts as a model for bone tissue engineering. J. Biomater. Appl. 2014, 29, 1394-1406. [CrossRef]

31. Hosseini, F.S.; Soleimanifar, F.; Aidun, A.; Enderami, S.E.; Saburi, E.; Marzouni, H.Z.; Khani, M.; Khojasteh, A.; Ardeshirylajimi, A. Poly (3-hydroxybutyrate-co-3-hydroxyvalerate) improved osteogenic differentiation of the human induced pluripotent stem cells while considered as an artificial extracellular matrix. J. Cell. Physiol. 2018, 234, 11537-11544. [CrossRef]

32. Li, W.; Cicek, N.; Levin, D.B.; Liu, S. Enabling electrospinning of medium-chain length polyhydroxyalkanoates (PHAs) by blending with short-chain length PHAs. Int. J. Polym. Mater. 2018, 68, 499-509. [CrossRef]

33. Panaitescu, D.M.; Lupescu, I.; Frone, A.N.; Chiulan, I.; Nicolae, C.A.; Tofan, V.; Stefaniu, A.; Somoghi, R.; Trusca, R. Medium Chain-Length Polyhydroxyalkanoate Copolymer Modified by Bacterial Cellulose for Medical Devices. Biomacromolecules 2017, 18, 3222-3232. [CrossRef]

34. Ndreu, A.; Nikkola, L.; Ylikauppila, H.; Ashammakhi, N.; Hasirci, V. Electrospun biodegradable nanofibrous mats for tissue engineering. Nanomedicine 2008, 3, 45-60. [CrossRef] [PubMed]

35. Kim, M.C.; Masuoka, T. Degradation properties of PLA and PHBV films treated with $\mathrm{CO}_{2}$-plasma. React. Funct. Polym. 2009, 69, 287-292. [CrossRef]

36. Mirmohammadi, S.A.; Khorasani, M.T.; Mirzadeh, H.; Irani, S. Investigation of plasma treatment on poly (3-hydroxybutyrate) film surface: Characterization and in vitro assay. Polym. Plast. Technol. Eng. 2012, 51, 1319-1326. [CrossRef]

37. Wang, Y.; Lu, L.; Zheng, Y.; Chen, X. Improvement in hydrophilicity of PHBV films by plasma treatment. J. Biomed. Mater. Res. Part A 2006, 76, 589-595. [CrossRef]

38. Denes, F.S.; Manolache, S. Macromolecular plasma-chemistry: An emerging field of polymer science. Prog. Polym. Sci. 2004, 29, 815-885. [CrossRef]

39. Kim, H.W.; Chung, C.W.; Kim, S.S.; Kim, Y.B.; Rhee, Y.H. Preparation and cell compatibility of acrylamide-grafted poly(3hydroxyoctanoate). Int. J. Biol. Macromol. 2002, 30, 129-135. [CrossRef]

40. Ke, Y.; Liu, C.; Zhang, X.; Xiao, M.; Wu, G. Surface modification of polyhydroxyalkanoates toward enhancing cell compatibility and antibacterial activity. Macromol. Mater. Eng. 2017, 302, 1700258. [CrossRef]

41. Cruz, M.V.; Sarraguça, M.C.; Freitas, F.; Lopes, J.A.; Reis, M.A. Online monitoring of P(3HB) produced from used cooking oil with near-infrared spectroscopy. J. Biotechnol. 2015, 194, 1-9. [CrossRef]

42. Wang, Y.; Chen, R.; Cai, J.; Liu, Z.; Zheng, Y.; Wang, H.; Li, Q.; He, N. Biosynthesis and Thermal Properties of PHBV Produced from Levulinic Acid by Ralstonia eutropha. PLoS ONE 2013, 8, e60318. [CrossRef]

43. Meneses, L.; Pereira, J.; Servin, C.; Grandfils, C.; Paiva, A.; Reis, M.A.M.; Freitas, F. Pseudomonas chlororaphis as a multiproduct platform: Conversion of glycerol into high-value biopolymers and phenazines. New Biotechnol. 2020, 55, 84-90. [CrossRef] [PubMed]

44. Pereira, J.R.; Araújo, D.; Marques, A.C.; Neves, L.A.; Grandfils, C.; Sevrin, C.; Alves, V.D.; Fortunato, E.; Reis, M.A.M.; Freitas, F. Demonstration of the adhesive properties of the medium-chain-length polyhydroxyalkanoate produced by Pseudomonas chlororaphis subsp. aurantiaca from glycerol. Int. J. Biol. Macromol. 2019, 122, 1144-1151. [CrossRef]

45. Morais, C.; Freitas, F.; Cruz, M.V.; Paiva, A.; Dionísio, M.; Reis, M.A.; Andrade, M.M.D. Conversion of fat-containing waste from the margarine manufacturing process into bacterial polyhydroxyalkanoates. Int. J. Biol. Macromol. 2014, 71, 68-73. [CrossRef] [PubMed]

46. Rebocho, A.T.; Pereira, J.R.; Freitas, F.; Neves, L.A.; Alves, V.D.; Sevrin, C.; Grandfils, C.; Reis, M.A. Production of medium-chain length polyhydroxyalkanoates by Pseudomonas citronellolis grown in apple pulp waste. Appl. Food Biotechnol. 2019, 6, 71-82.

47. Singh, M.; Kumar, P.; Ray, S.; Kalia, V.C. Challenges and Opportunities for Customizing Polyhydroxyalkanoates. Indian J. Microbiol. 2015, 55, 235-249. [CrossRef]

48. Kunasundari, B.; Sudesh, K. Isolation and recovery of microbial polyhydroxyalkanoates. Express Polym. Lett. 2011, 5, 620-634. [CrossRef]

49. Pillay, V.; Dott, C.; Choonara, Y.E.; Tyagi, C.; Tomar, L.; Kumar, P.; Du Toit, L.C.; Ndesendo, V.M.K. A Review of the Effect of Processing Variables on the Fabrication of Electrospun Nanofibers for Drug Delivery Applications. J. Nanomater. 2013, $2013,1-22$. [CrossRef]

50. Henriques, C.; Vidinha, R.; Botequim, D.; Borges, J.P.; Silva, J.A.M.C. A Systematic Study of Solution and Processing Parameters on Nanofiber Morphology Using a New Electrospinning Apparatus. J. Nanosci. Nanotechnol. 2009, 9, 3535-3545. [CrossRef] 
51. Azari, P.; Yahya, R.; Wong, C.S.; Gan, S.N. Improved processability of electrospun poly[(R)-3-hydroxybutyricacid] through blending with medium-chain length poly(3-hydroxyalkanoates) produced by Pseudomonas putida from oleic acid. Mater. Res. Innov. 2014, 18, 345-349. [CrossRef]

52. Puppi, D.; Pecorini, G.; Chiellini, F. Biomedical Processing of Polyhydroxyalkanoates. Bioengineering 2019, 6, 108. [CrossRef] [PubMed]

53. Köse, G.; Kenar, H.; Hasırc1, N.; Hasırc1, V.; Hasirci, N.; Hasirci, V. Macroporous poly(3-hydroxybutyrate-co-3-hydroxyvalerate) matrices for bone tissue engineering. Biomaterials 2003, 24, 1949-1958. [CrossRef]

54. Köse, T.; Ber, S.; Korkusuz, F.; Hasirci, V. Poly(3-hydroxybutyric acid-co-3-hydroxyvaleric acid) based tissue engineering ma-trices. J. Mat. Sci. Mat. Med. 2003, 14, 121-126. [CrossRef]

55. Chen, M.; Patra, P.K.; Lovett, M.L.; Kaplan, D.L.; Bhowmick, S. Role of electrospun fibre diameter and corresponding specific surface area (SSA) on cell attachment. J. Tissue Eng. Regen. Med. 2009, 3, 269-279. [CrossRef] [PubMed]

56. Wang, X.; Lou, T.; Zhao, W.; Song, G.; Li, C.; Cui, G. The effect of fiber size and pore size on cell proliferation and infiltration in PLLA scaffolds on bone tissue engineering. J. Biomater. Appl. 2016, 30, 1545-1551. [CrossRef] [PubMed]

57. Organ, S. Variation in melting point with molecular weight for hydroxybutyrate/hydroxyvalerate copolymers. Polymer 1993, 34, 2175-2179. [CrossRef]

58. Mottin, A.C.; Ayres, E.; Orefice, R.L.; Câmara, J.J.D. What changes in poly(3-hydroxybutyrate) (PHB) when processed as electrospun nanofibers or thermo-compression molded film? Mater. Res. 2016, 19, 57-66. [CrossRef]

59. Law, K.-Y. Definitions for Hydrophilicity, Hydrophobicity, and Superhydrophobicity: Getting the Basics Right. J. Phys. Chem. Lett. 2014, 5, 686-688. [CrossRef]

60. Lee, Y.; Sridewei, N.; Ramanathan, S.; Sudesh, K. The influence of electrospinning parameters and drug loading on polyhydroxyalkanoate (pha) nanofibers for drug delivery. Int. J. Biotech. Well. Ind. 2017, 4, 103-113.

61. Correia, D.; Ribeiro, C.; Ferreira, J.C.; Botelho, G.; Ribelles, J.L.G.; Lanceros-Méndez, S.; Sencadas, V. Influence of electrospinning parameters on poly(hydroxybutyrate) electrospun membranes fiber size and distribution. Polym. Eng. Sci. 2013, 54, 1608-1617. [CrossRef]

62. Ouyang, S.P.; Luo, R.C.; Chen, S.S.; Liu, Q.; Chung, A.; Wu, Q.; Chen, G.Q. Production of polyhydroxyalkanoates with high 3-hydroxydodecanoate monomer content by fadB and fadA knockout mutant of Pseudomonas putida KT2442. Biomacromolecules 2007, 8, 2504-2511. [CrossRef] [PubMed]

63. Gumel, A.; Annuar, M.; Heidelberg, T. Growth kinetics, effect of carbon substrate in biosynthesis of mcl-PHA by Pseudomonas putida Bet001. Braz. J. Microbiol. 2014, 45, 427-438. [CrossRef] [PubMed]

64. Hoyle, H.W.; Smith, L.A.; Williams, R.J.; Przyborski, S.A. Applications of novel bioreactor technology to enhance the viability and function of cultured cells and tissues. Interface Focus 2020, 10, 20190090. [CrossRef]

65. Brancato, V.; Oliveira, J.M.; Correlo, V.M.; Reis, R.L.; Kundu, S.C. Could 3D models of cancer enhance drug screening? Biomaterialis 2020, 232, 119744. [CrossRef]

66. Dikici, B.A.; Sherborne, C.; Reilly, G.C.; Claeyssens, F. Emulsion templated scaffolds manufactured from photocurable polycaprolactone. Polymer 2019, 175, 243-254. [CrossRef]

67. Giancotti, F.G.; Ruoslahti, E. Integrin signaling. Science 1999, 285, 1028-1033. [CrossRef] [PubMed]

68. Fomby, P.; Cherlin, A.J.; Hadjizadeh, A.; Doillon, C.J.; Sueblinvong, V.; Weiss, D.J.; Bates, J.H.T.; Gilbert, T.; Liles, W.C.; Lutzko, C.; et al. Stem cells and cell therapies in lung biology and diseases: Conference report. Ann. Am. Thorac. Soc. 2010, 12, 181-204.

69. Karahaliloğlu, Z. Cell-compatible PHB/silk fibroin composite nanofiber mat for tissue engineering applications. Turkish J. Biol. 2017, 41, 503-513. [CrossRef] 